Pacific Northwest

National Laboratory

Operated by Battelle for the

U.S. Department of Energy

\section{Interim Status Groundwater Monitoring Plan for Low-Level Waste Management Areas 1 to 4, RCRA Facilities, Hanford, Washington}

P. E. Dresel

September 2004

\footnotetext{
Prepared for the U.S. Department of Energy
} under Contract DE-AC06-76RL01830 


\title{
DISCLAIMER
}

This report was prepared as an account of work sponsored by an agency of the United States Government. Neither the United States Government nor any agency thereof, nor Battelle Memorial Institute, nor any of their employees, makes any warranty, express or implied, or assumes any legal liability or responsibility for the accuracy, completeness, or usefulness of any information, apparatus, product, or process disclosed, or represents that its use would not infringe privately owned rights. Reference herein to any specific commercial product, process, or service by trade name, trademark, manufacturer, or otherwise does not necessarily constitute or imply its endorsement, recommendation, or favoring by the United States Government or any agency thereof, or Battelle Memorial Institute. The views and opinions of authors expressed herein do not necessarily state or reflect those of the United States Government or any agency thereof.

\author{
PACIFIC NORTHWEST NATIONAL LABORATORY \\ operated by \\ BATTELLE \\ for the \\ UNITED STATES DEPARTMENT OF ENERGY \\ under Contract DE-AC06-76RL01830
}

Ty 


\section{Interim Status Groundwater Monitoring Plan for Low-Level Waste Management Areas 1 to 4, RCRA Facilities, Hanford, Washington}

P. E. Dresel

September 2004

Prepared for

the U.S. Department of Energy

under Contract DE-AC06-76RL01830

Pacific Northwest National Laboratory

Richland, Washington 99352 


\section{Summary}

This document describes the monitoring plan to meet the requirements for interim status groundwater monitoring at Hanford Site low-level waste burial grounds as specified by 40 CFR 265, incorporated by reference in WAC 173-303-400. The monitoring will take place at four separate low-level waste management areas in the 200-West and 200-East Areas, in the central part of the site. This plan replaces the previous monitoring plan.

This plan briefly describes the regulatory framework, site characteristics, and hydrogeologic setting of the areas to be monitored. It summarizes the previous monitoring results and outlines a conceptual model for possible contaminant transport from the burial grounds.

This plan specifies the wells and constituents and frequency of monitoring, which includes new wells that have been proposed for installation in fiscal year 2005 as part of Tri-Party Agreement (TPA) Milestone M-24. Sampling and analysis protocols, quality assurance/quality control requirements, and methods of data management, interpretation, and reporting are described. Appendix A summarizes the Sampling and Analysis Plan. 


\section{Contents}

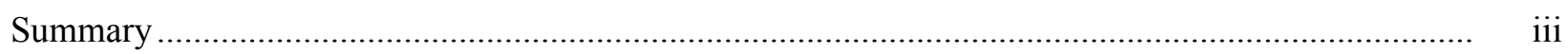

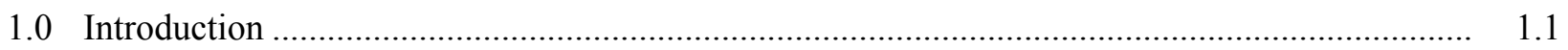

1.1 Regulatory Framework ............................................................................................... 1.1

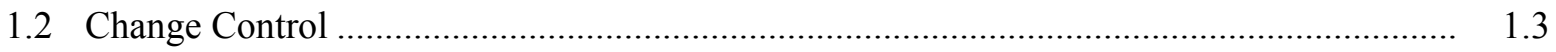

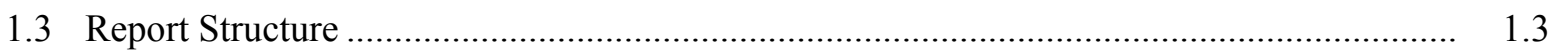

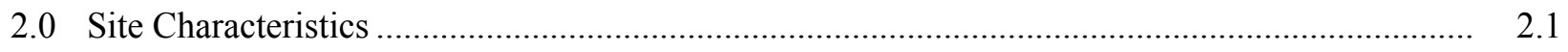

$2.1 \quad$ Waste Characteristics ................................................................................................. 2.1

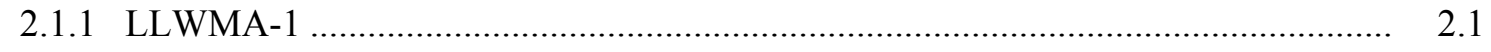

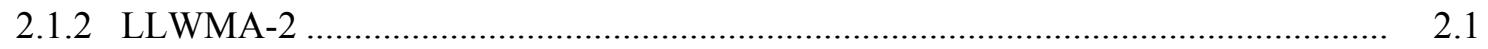

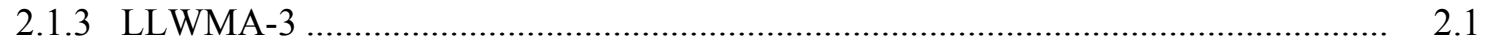

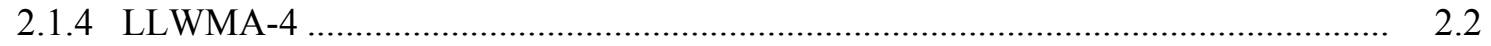

2.2 Geology/Hydrogeology .................................................................................... 2.2

2.3 Summary of Previous Groundwater Monitoring............................................................... 2.4

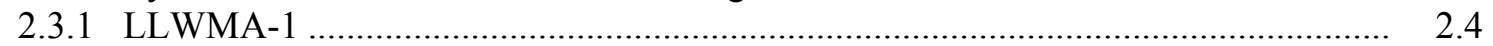

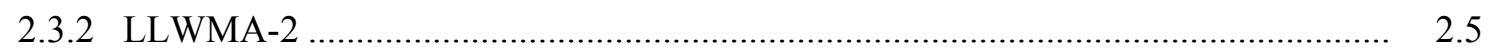

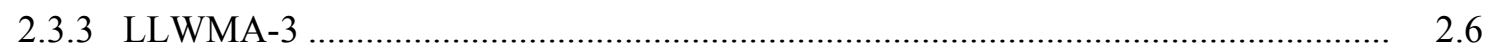

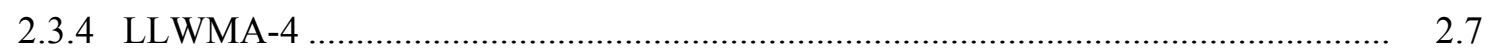

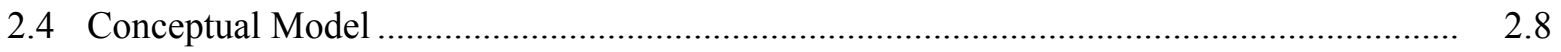

2.4.1 Geochemical Considerations ........................................................................... 2.8

2.4.2 Vadose Zone Transport and Minimum Travel Time............................................... 2.8

2.4.3 Constituents of Potential Concern for Groundwater Monitoring .............................. 2.9

3.0 Groundwater Monitoring Program ………………………………………………….......... 3.1

3.1 Constituent List and Sampling Frequency ........................................................................ 3.1

3.1.1 Differences from Previous Monitoring ………………………………………..... 3.1

3.2 Monitoring Well Network ........................................................................................... 3.1

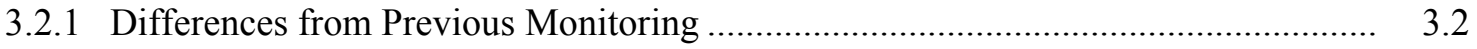

3.2.2 New Wells ........................................................................................... 3.2

3.3 Sampling and Analysis Protocol ………………………............................................ 3.5

3.3.1 Scheduling Groundwater Sampling ....................................................................... 3.5

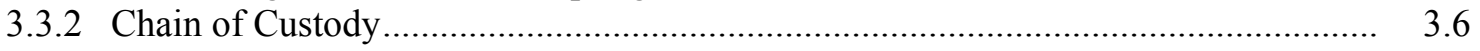

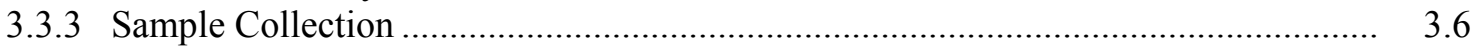

3.4.4 Analytical Protocols ...................................................................................... 3.6 


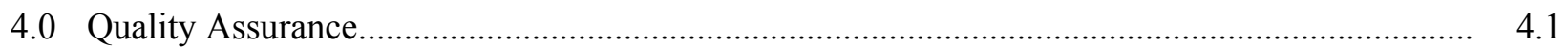

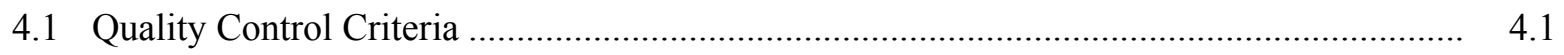

4.2 Groundwater Data Validation Process ........................................................................ 4.3

$5.0 \quad$ Data Management, Evaluation, and Reporting ............................................................. 5.1

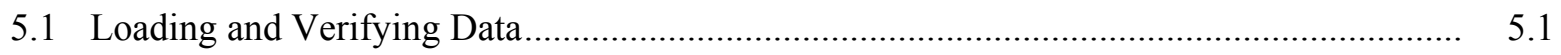

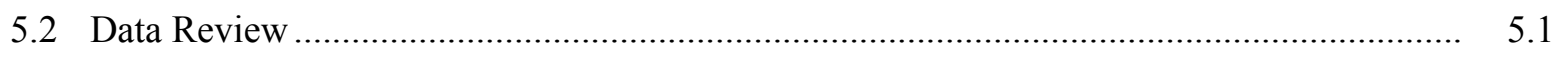

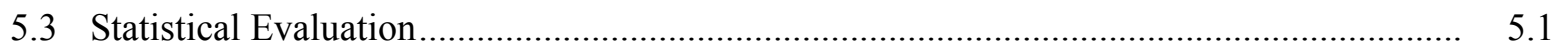

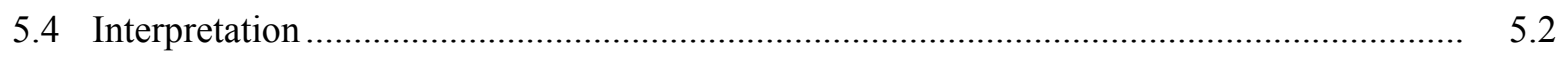

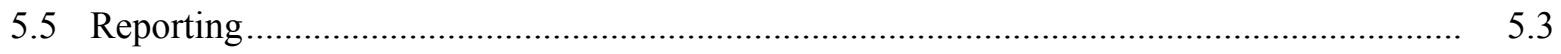

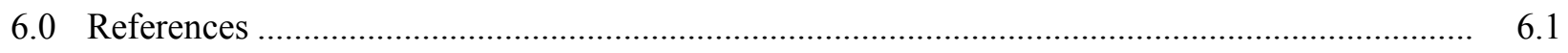

Appendix A - Sampling and Analysis Plan for Hanford Site Low-Level Waste Management Areas 1 to 4 RCRA Interim Status Groundwater Detection Monitoring Appendix B - Groundwater Quality Assessment Program Outline

\section{Figures}

1.1 Location of Hanford Site Low-Level Waste Management Areas .......................................... 1.2

2.1 Comparison of Generalized Hydrogeologic and Geologic Stratigraphy ................................. 2.3

3.1 Locations for Proposed New Wells at LLWMA-3 _.............................................................

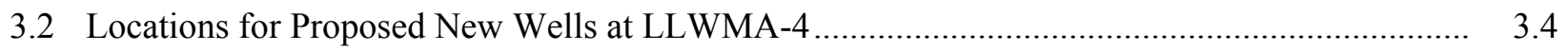




\section{Tables}

1.1 Low-Level Waste Management Areas Covered by this Plan and the Burial Grounds Contained in Each.

4.1 Quality Control Samples

4.2 Recovery Limits for Double Blind Standards 


\subsection{Introduction}

The low-level burial grounds (LLBGs) are located in the 200-West and 200-East Areas of the Hanford Site in southeastern Washington State. For the purposes of groundwater monitoring, the LLBGs are grouped into four Low-Level Waste Management Areas (LLWMAs): LLWMA-1, LLWMA-2, LLWMA-3, and LLWMA-4 (Table 1.1, Figure 1.1). A fifth area, LLWMA-5, has not received any waste so it will not be considered in this plan. The LLBGs received, and continue to receive, dry radioactive and mixed waste from U.S. Department of Energy (DOE) operations onsite and offsite, as directed by DOE.

This plan describes the monitoring required under the Resource Conservation and Recovery Act (RCRA) as implemented by the state of Washington dangerous waste regulations. The plan supercedes the previous monitoring plan (Last and Bjornstad 1989). A revised plan is needed because the previous plan had already been modified extensively through change notices and is not current due to wells going dry, as described in a letter to Washington State Department of Ecology (Ecology). ${ }^{1}$ This new plan documents the updated monitoring system. Final status monitoring is expected to replace this plan upon incorporation of the LLBG into the Hanford Facility RCRA Permit (Ecology 1994).

Table 1.1. Low-Level Waste Management Areas Covered by this Plan and the Burial Grounds Contained in Each

\begin{tabular}{||c|c|c||}
\hline $\begin{array}{c}\text { Low-Level Waste } \\
\text { Management Area }\end{array}$ & Location & Burial Grounds \\
\hline \hline 1 & Northwestern 200-East Area & $218-\mathrm{E}-10$ \\
\hline 2 & Northeastern 200-East Area & $218-\mathrm{E}-12 \mathrm{~B}$ \\
\hline 3 & Northwestern 200-West Area & $218-\mathrm{W}-3 \mathrm{~A}$ \\
& & $218-\mathrm{W}-3 \mathrm{AE}$ \\
& & $218-\mathrm{W}-5$ \\
\hline 4 & Western 200-West Area & $218-\mathrm{W}-4 \mathrm{~B}$ \\
& & $218-\mathrm{W}-4 \mathrm{C}$ \\
\hline
\end{tabular}

\subsection{Regulatory Framework}

Certain wastes within the LLWMAs are regulated under Subtitle C, Hazardous Waste Management of RCRA. RCRA regulations are implemented under the authority of Washington State Dangerous Waste Regulations (WAC-173-303). Groundwater monitoring specified in 40 CFR 265 Subpart F (40 CFR 265.90 through 265.94) is incorporated by reference into WAC 173-303-400. In the early 1980s, DOE submitted Part A of its permit application (modified on several occasions since then) that qualified DOE for interim status for a number of hazardous waste activities.

\footnotetext{
${ }^{1}$ Letter 02-WMD-0269 from U.S. Department of Energy, Richland Operations Office to Washington State Department of Ecology, Status of Groundwater Monitoring at the Low-Level Burial Ground (LLBG), dated August 22, 2002.
} 

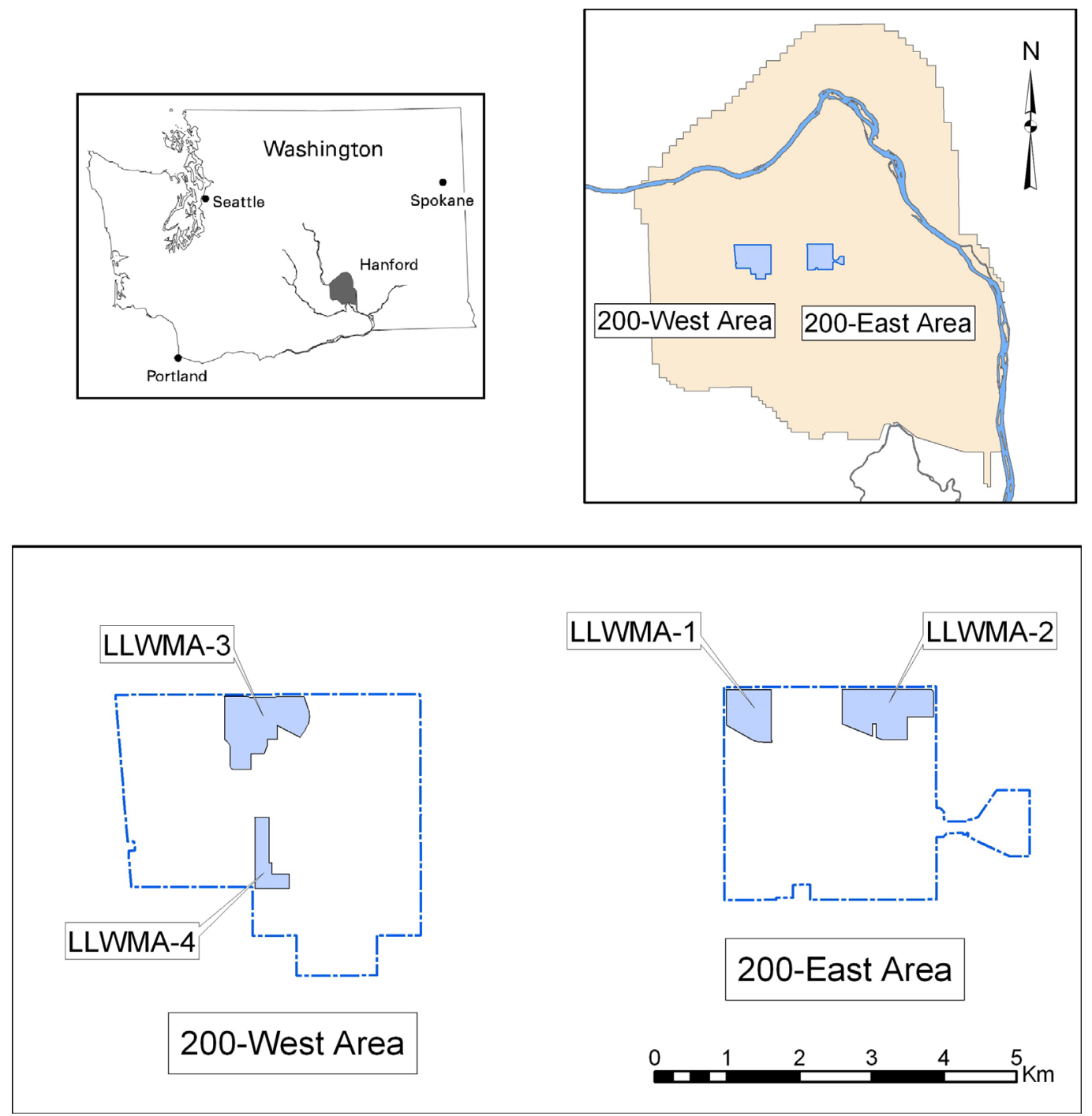

Figure 1.1. Location of Hanford Site Low-Level Waste Management Areas

Monitoring of radionuclides at the LLWMAs is carried out for performance assessment to meet requirements of the Atomic Energy Act of 1954 (AEA), as implemented by DOE orders, specifically Order 435.1, Radioactive Waste Management. At the time of preparation of this plan, the performance assessment monitoring under the AEA was performed per DOE (2000).

Source, special nuclear, and by-product materials, as defined in AEA, are regulated at DOE facilities exclusively by DOE acting pursuant to its AEA authority. These materials are not subject to regulation by the state of Washington. All information contained herein and related to, or describing AEA-regulated materials and processes in any manner, may not be used to create conditions or other restrictions set forth in any permit, license, order, or any other enforceable instrument. DOE asserts that pursuant to the AEA, it has sole and exclusive responsibility and authority to regulate source, special nuclear and by-product materials at DOE-owned nuclear facilities. Information contained herein on radionuclides is provided for process description purposes only. 
Groundwater monitoring is also performed at or near the LLWMAs for RCRA past-practice purposes or Comprehensive, Environmental Response, Compensation, and Liability Act (CERCLA). LLWMA-1 and LLWMA-2, in the 200-East Area, fall within the 200-BP-5 Groundwater Operable Unit. LLWMA-3 and LLWMA-4 in 200-West Area fall within the 200-ZP-1 Groundwater Operable Unit (a small part of LLWMA-4 is technically within the 200-UP-1 Groundwater Operable Unit).

CERCLA and AEA monitoring complement the information from the RCRA monitoring and provides additional context for interpretation of the RCRA monitoring results. In some cases, the same constituents are monitored for other programs as well as the RCRA requirements. In that situation, the sampling is combined to avoid redundancy and increase efficiency of monitoring.

\subsection{Change Control}

Periodically, it may be necessary to modify the sampling performed at the LLWMAs. Minor modifications such as changes to analytical methods (while still meeting equivalent or better performance criteria) do not require modification to this document and will be documented in the project files. Occasionally, additional samples will be collected or additional analyses performed to investigate unusual results or confirm results that exceed statistical comparison values. These additions will be documented in project files. Changes to sampling dates may occur so cosampling for other objectives is optimized or if scheduling or equipment problems occur. These changes will be documented in project files unless they permanently alter the monitoring under this plan.

Interim Change Notices (ICNs) will be issued for other changes to the well network or constituent lists and for other small updates. For example, if wells cannot be sampled and must be removed from the well network, a change request will be submitted to the sampling and analysis task and an ICN will be prepared, documenting the justification for the change. Revisions to this document may be made to document more extensive changes or to incorporate several ICNs into this plan.

\subsection{Report Structure}

Section 2 of this report provides background data on the waste operations, and hydrogeology. It discusses other monitoring activities in the vicinity of the LLWMAs and summarizes important aspects of previous groundwater monitoring. This includes a listing of constituents of interest for RCRA monitoring at the LLWMAs and a description of regional contamination, which is not believed to originate in the burial grounds.

Section 3 of this report describes the RCRA groundwater monitoring to be instituted at the LLWMAs. The monitoring well network, sampling frequency, and sampling protocols are discussed. The specific description of the sampling and analysis plan will be deferred to Appendix A to facilitate sample scheduling and streamline sampling and analysis changes.

Section 4 contains information on the project's quality control procedures and how they support this plan. Section 5 discusses the way data are managed, evaluated, and reported. 


\subsection{Site Characteristics}

\subsection{Waste Characteristics}

This section provides a brief description of the waste in each LLWMA. In addition to RCRAregulated dangerous and mixed waste, the LLWMAs contain low-level waste and retrievable transuranic waste. Waste disposal in the LLWMAs started in the 1960s, prior to the promulgation and application of RCRA regulations. There is considerable uncertainty about the nature of the early waste disposed in the burial grounds. Some of the early waste (pre-RCRA) disposed as radioactive waste may also contain chemicals of environmental concern.

\subsubsection{LLWMA-1}

LLWMA-1 contains a single burial ground, 218-E-10. The 218-E-10 burial ground is approximately 36.1 hectares in size and began receiving waste in 1960. Examples of waste placed in this burial ground include failed equipment, rags, paper, rubber gloves, disposable supplies, and broken tools. Only a few small areas in one trench received post-August 19, 1987 mixed waste.

\subsubsection{LLWMA-2}

LLWMA-2 contains a single burial ground, 218-E-12B. The 218-E-12B burial ground is approximately 68 hectares in size and began receiving waste in 1967. The only post-August 19, 1987, mixed waste is in the large trench containing defueled naval reactor compartments (Trench 94). The waste packages containing the reactor compartments have not been buried and are completely exposed above the pit bottom. The only constituent in the reactor compartments that may be considered dangerous waste under WAC 173-303 is state only regulated lead shielding. The shielding is encased in steel, all drainable liquids have been removed, and the whole package exterior is constructed of welded steel, often including the vessel hull.

\subsubsection{LLWMA-3}

LLWMA-3 contains the 218-W3-A burial ground (approximately 20.4 hectares), 218-W-3AE burial ground (approximately 20 hectares), and 218-W-5 burial ground (approximately 37.2 hectares). The 218-W-3A burial ground began receiving waste in 1970. Examples of waste placed in this burial ground include ion exchange resins, failed equipment, tanks, pumps, ovens, agitators, heaters, hoods, jumpers, vehicles, and accessories. Only a few areas in two trenches received mixed waste after August 19, 1987. The 218-W-3AE burial ground began receiving waste in 1981. Examples of waste placed in this burial ground include rags, paper, rubber gloves, disposable supplies, and broken tools. Only a few areas in two trenches received mixed waste after August 19, 1987. The 218-W-5 burial ground began receiving waste in 1986. Examples of waste placed in this burial ground include rags, paper, rubber gloves, disposable supplies, and broken tools. This burial ground currently contains two double-lined mixed waste trenches (Trenches 31 and 34). Adjacent to the double lined mixed waste trenches are leachate collection tanks. Aside from the lined trenches, one small area in one unlined trench received mixed waste after August 19, 1987. 


\subsubsection{LLWMA-4}

LLWMA-4 contains the 218-W-4B burial ground (approximately 3.5 hectares) and 218-W-4C burial ground (approximately 20 hectares). The 218-W-4B burial ground began receiving waste in 1968 . Examples of waste placed in this burial ground include rags, paper, rubber gloves, disposable supplies, and broken tools and contains no post-August 19, 1987, mixed waste. In addition to the waste trenches, waste is stored in 11 vertical caissons in the southern part of the burial ground. The $218-\mathrm{W}-4 \mathrm{C}$ burial ground began receiving waste in 1978. Examples of waste placed in this burial ground include contaminated soil, decommissioned pumps, and pressure vessels. Only a few areas in three trenches received mixed waste after August 19, 1987.

\subsection{Geology/Hydrogeology}

The hydrogeologic setting of the Hanford Site is described in Hartman (2000). The aquifers beneath the Hanford Site can be divided broadly into the basalt confined aquifers and suprabasalt aquifers. The most recent hydrogeologic summaries of the suprabasalt aquifer system in the 200-East Area, where LLWMA-1 and LLWMA-2 are located, were published in Williams et al. (2000). The most recent summary of the suprabasalt hydrogeology in the 200-West Area, including LLWMA-3 and LLWMA-4, was published in Williams et al. (2002). Figure 2.1 shows the generalized hydrogeologic and geologic stratigraphy presented in Williams et al. (2002).

The uppermost unconfined aquifer beneath LLWMA-1 and LLWMA-2 is contained in hydrogeologic unit 1 (Hanford formation). This unit is comprised of unconsolidated pebble to boulder gravels, fine-tocoarse-grained sand, and some silt-to-clayey silt. Beneath the northern part of LLWMA-2, the unconfined aquifer is absent because the basalt surface rises above the water table. This makes groundwater monitoring in those areas impractical. The uppermost unconfined aquifer beneath LLWMA-3 and LLWMA-4 is within hydrogeologic unit 5 (Ringold Unit E). This unit is comprised primarily of fluvial gravel that grades upward into interbedded fluvial sand and silt.

Hydraulic gradient and groundwater flow direction must be defined in order to monitor effectively and to apply statistical tests required by RCRA interim status regulations. Gradients are very flat across the 200-East Area due to the high permeability of the Hanford formation sediments, so it is difficult to define the gradient for LLWMA-1 and LLWMA-2. Gradients are higher in the 200-West Area due to the lower permeability of the Ringold Formation sediments but flow directions in LLWMA-3 and LLWMA-4 are affected by changing contributions from artificial recharge during Hanford Site operations and the impacts of pump-and-treat remediation extraction and injection wells. The flow direction and magnitude of the gradient for each LLWMA are discussed in the following paragraphs.

Flow direction has been to the northwest at LLWMA-1 in recent years, based on contaminant plumes and water-level data. However, in fiscal year 2003, trend surface analysis of water levels yielded highly variable flow directions. In fiscal year 2003, the declining trend in water levels within the 200-East Area slowed and in some wells the water levels increased (Hartman et al. 2004). For these reasons, no attempt will be made to update the designation of wells as upgradient or downgradient until a stable flow direction is reestablished. 


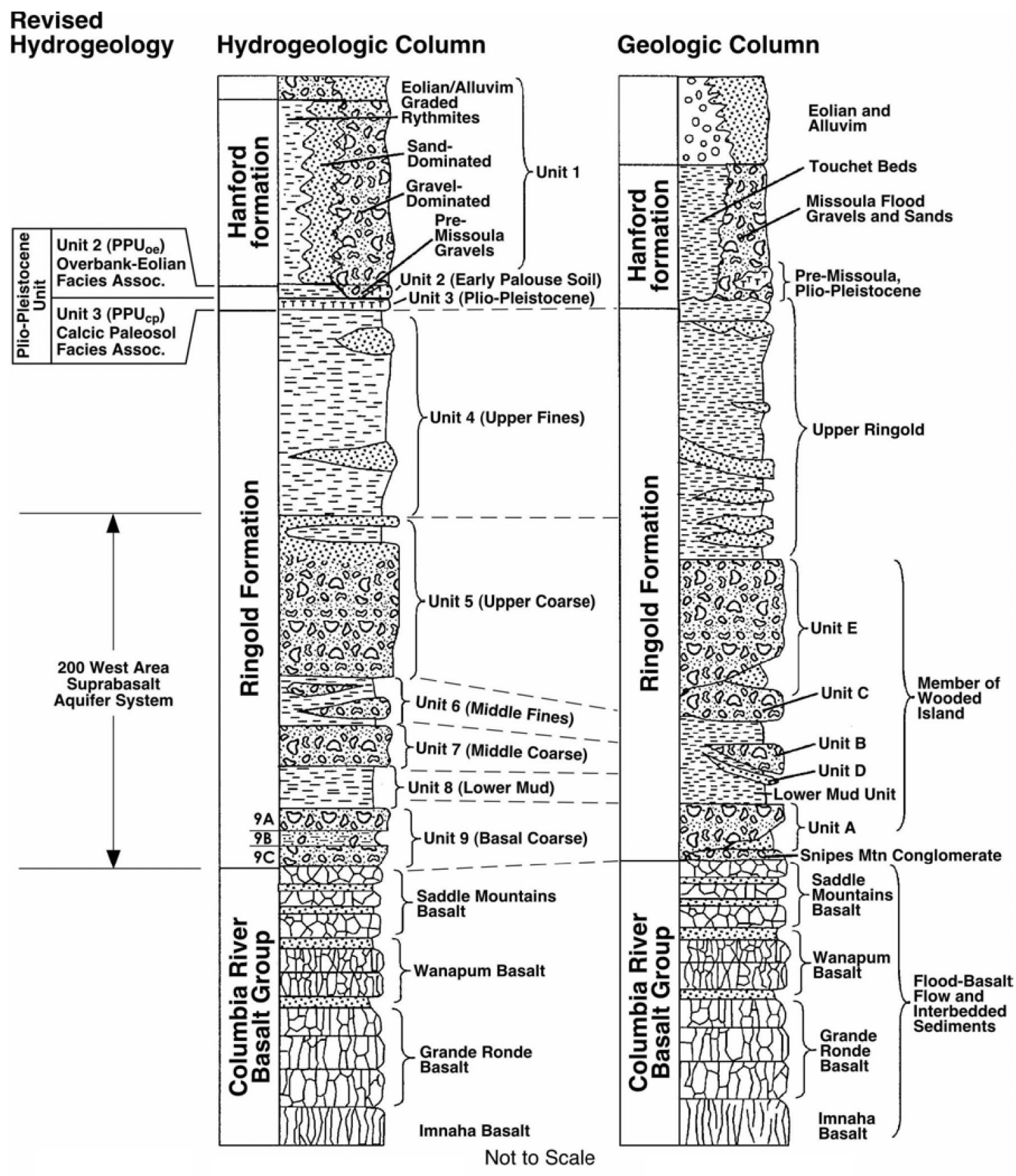

2002/DCL/200W HGS/002

Figure 2.1. Comparison of Generalized Hydrogeologic and Geologic Stratigraphy (from Williams et al. 2002) 
Flow direction at LLWMA-2 has been generally to the west, under the influence of groundwater mounding at B Pond, east of the area. In fiscal year 2002, trend surface analysis indicated flow generally to the southwest, but no realistic determination of flow direction could be made from trend surface analysis of fiscal year 2003 data. The basalt surface above the water table in the north part of LLWMA-2 constrains possible flow directions in the unconfined aquifer. However, it is possible that flow is influenced by continued drainage of the unsaturated sediment and recharge flowing down the basalt surface to the saturated aquifer sediment. For these reasons, no attempt will be made to update the designation of wells as upgradient or downgradient until a stable flow direction is reestablished.

Flow direction at LLWMA-3 was to the north-northeast near the start of RCRA groundwater monitoring, in the late 1980s (Last and Bjornstad 1989). With the cessation of most waste-water discharges to ground, groundwater flow has shifted toward the east. In fiscal year 2003, the flow direction was determined to be to the east-northeast (70 degrees). It is likely that flow will shift further to the east as water levels continue to decline, barring any additional influence from remediation systems.

Flow direction at LLWMA-4 was generally to the west and northwest near the start of RCRA groundwater monitoring, in the late 1980s (Last and Bjornstad 1989). With the cessation of most waste-water discharges to ground and the initiation of pump-and-treat remediation for the 200-ZP-1 Groundwater Operable Unit, groundwater flow generally has reversed to the east. Flow direction varies somewhat with location in the waste management area and with operation of the remediation system. Treated water is reinjected into the aquifer west of LLWMA-4 so the system affects the upgradient chemistry as well as the gradient.

\subsection{Summary of Previous Groundwater Monitoring}

\subsubsection{LLWMA-1}

\subsubsection{History of Monitoring Networks}

Monitoring wells at LLWMA-1 were installed between 1987 and 1992 for RCRA interim status detection monitoring. Sampling across the Hanford Site was suspended for a period in fiscal year 1990 and 1991. A pre-existing monitoring well 299-E32-1 was monitored until 1990 and replaced with well 299-E32-7, which was drilled in 1991. All other wells installed for RCRA monitoring remain as part of the network. In or about 1993, the flow direction was re-evaluated and the designation of wells as upgradient or downgradient was updated.

\subsubsection{Exceedance of Statistical Comparison Values}

Specific conductance in well 299-E28-26, then considered downgradient, exceeded the upgradientdowngradient comparison value in 1990, triggering assessment monitoring. However, assessment monitoring concluded that the elevated specific conductance was caused by nitrate and other constituents from upgradient facilities (Mercer 1993a). The monitoring reverted to detection monitoring in 1994.

DOE informed Ecology in 1999 that a nitrate plume from upgradient sources was impacting downgradient well 299-E33-34 in the northeast corner of LLWMA-1. Specific conductance continues to 
exceed the upgradient-downgradient statistical comparison value in this well due to this upgradient plume. Because no waste has been placed in the north part of the burial ground and because of the known upgradient sources, no further action is deemed necessary. An exceedance of the statistical comparison value in well 299-E32-10 in fiscal year 2002 is also attributed to the nitrate plume.

\subsubsection{Regional Contamination}

The groundwater beneath LLWMA-1 is impacted by regional contamination. The most significant chemical contaminants identified are nitrate and cyanide from the vicinity of the BY cribs to the east (and may include some contamination from the B-BX-BY Tank Farms and other nearby cribs). Cyanide is not currently found at levels greater than its drinking water standard in LLWMA-1 wells. Nitrate contamination also originates in cribs to the south and southeast near B Plant, and possibly from cribs near the PUREX Plant. The highest levels of contamination are associated with the BY cribs and impact the northeast corner of LLWMA-1. The area impacted by the BY crib plumes has not been used for waste disposal. Regional contamination across the south/southwest part of LLWMA-1 does impact groundwater beneath waste trenches.

\subsubsection{LLWMA-2}

\subsubsection{History of Monitoring Networks}

RCRA monitoring wells at LLWMA-2 were installed between 1987 and 1992. Sampling across the Hanford Site was suspended for a period in fiscal year 1990 and 1991. Five of the 16 wells installed for RCRA monitoring at LLWMA-2 have gone dry and been removed from the monitoring network. Replacement of the wells that have gone dry is impracticable because the unconfined aquifer above the basalt surface is very thin or non-existent, and the basalt will not produce enough water to be sampled. There is no unconfined aquifer beneath much of the LLWMA.

\subsubsection{Exceedance of Statistical Comparison Values}

No downgradient exceedance of statistical comparison values has been confirmed at LLWMA-2. Upgradient well 299-E34-7 has had significant increases in specific conductance in recent years and is now well over the comparison value. This increase is related primarily to an increase in sulfate, chloride, nitrate, sodium, and calcium. Nitrate is found at levels above the drinking water standard.

Total organic carbon (TOC) also has been increasing in well 299-E34-7. Analysis for oil and grease (April 2001) reported $1.7 \mathrm{mg} / \mathrm{L}$; however, oil and grease were not detected subsequently until $1.2 \mathrm{mg} / \mathrm{L}$ were detected in one of two replicates in April 2004. Volatile and semi-volatile organic analyses were negative for samples taken from this well with the exception of low-levels of endrin aldehyde $(0.08 \mu \mathrm{g} / \mathrm{L})$ in a sample collected in October 2002, sporadic detection of phthalates that may be laboratory contamination, and sporadic detections of chloromethane and methylene chloride. The low-level detections do 
not explain the levels of TOC. Total organic halides also have shown an increase in this well. The source has not been determined for any of these constituents, but the area of the burial ground near this well does not contain any organic dangerous wastes.

\subsubsection{Regional Contamination}

Relatively few regional chemical contaminant plumes affect the groundwater beneath LLWMA-2. Nitrate contamination is found at levels below the drinking water standard in several locations and at levels above the drinking water standard in upgradient wells 299-E34-7 and 299-E27-10.

\subsubsection{LLWMA-3}

\subsubsection{History of Monitoring Networks}

Monitoring wells were installed at LLWMA-3 between 1987 and 1993. Sampling across the Hanford Site was suspended for a period in fiscal year 1990 and 1991. Well 299-W7-4 was initially installed as an upgradient monitoring well, but changes in the burial ground boundary caused this well to be downgradient of portions of the burial ground. Three additional upgradient wells (299-W10-19, 299-W10-20, and 299-W10-21) were installed in 1992 and 1993. Twelve of the 20 wells that have been part of the RCRA monitoring network have gone dry and are no longer sampled. Several other wells are expected to go dry for sampling purposes in the next few years.

Flow direction at LLWMA-3 was originally toward the north-northeast. However, flow has shifted and is now toward the east-northeast. Thus, wells 299-W10-19, 299-W10-20, and 299-W10-21, which are designated as upgradient wells, are now downgradient of parts of the LLWMA. However, they continue to be impacted by contaminants from upgradient sources and, therefore, have been treated as upgradient wells for statistical comparison purposes. This plan reclassifies these wells as downgradient wells (see Section 5.3).

\subsubsection{Exceedance of Statistical Comparison Values}

In 1989, total organic halides in downgradient well 299-W7-4 exceeded the comparison value when it was redefined as a downgradient well (see Section 2.4.3.1), and TOC was determined to be above the statistical comparison value in downgradient wells 299-W7-5 and 299-W8-1. A groundwater assessment program (Chamness et al. 1990) was initiated. Analytical results from three additional upgradient monitoring wells indicated that the elevated total organic halides came from an upgradient source. An assessment report was prepared (Mercer 1993b) and detection level monitoring resumed.

\subsubsection{Regional Contamination}

The groundwater beneath much of LLWMA-3 is impacted by contamination from upgradient sources. This includes carbon tetrachloride, chloroform, trichloroethene, and nitrate as reported in Mercer (1993b), and confirmed by subsequent monitoring. The regional contamination moved into the area under past flow conditions, when the flow had a greater component toward the north. With flow shifting more toward the east, the changing flow direction must be considered in interpretations of the contaminant 
distribution and in application of statistical tests. The distribution of contaminants across the burial ground shows higher concentrations in the east (now downgradient) than in the west (now upgradient). When new upgradient wells are installed on the west side of LLWMA-3, the statistical upgradient comparison values will likely be exceeded in downgradient wells due to the distribution of regional contaminants alone.

\subsubsection{LLWMA-4}

\subsubsection{History of Monitoring Networks}

Monitoring wells were installed at LLWMA-4 between 1987 and 1992. The original monitoring network included 17 wells. One well, 299-W18-29, was completed in a perched aquifer but went dry soon after it was drilled. Sampling across the Hanford Site was suspended for a period in fiscal year 1990 and 1991. Flow was toward the west at the beginning of RCRA monitoring, but the hydraulic gradient altered dramatically with the termination of discharges to U Pond and other facilities. The initiation of pump-and-treat groundwater remediation for the 200-ZP-1 Groundwater Operable Unit also impacts groundwater flow and quality at LLWMA-4. The pump-and-treat extraction wells are located northeast and east of the north part of the burial grounds, and the injection wells are located west of the burial grounds.

The monitoring network was updated in 1998 to redefine the upgradient and downgradient wells. Four shallow wells were chosen to monitor upgradient conditions and three shallow wells were chosen to monitor downgradient of the burial grounds. In addition, one deep upgradient well and one shallow upgradient well were kept in the monitoring network. Since that time wells have gone dry, leaving three shallow and one deep upgradient wells and one deep downgradient well.

\subsubsection{Exceedance of Statistical Comparison Values}

After the monitoring network was updated in 1998 to reflect the changing flow directions, the newlydesignated downgradient well, 299-W15-16, exceeded the statistical comparison value for total organic halides. The exceedance is attributed to the regional carbon tetrachloride plume, which moved into the area under past flow conditions. This was reported to the Ecology in August 1999. Total organic halides continued to exceed the comparison value in this wall but were declining until the well went dry.

\subsubsection{Regional Contamination}

LLWMA-4 is affected by regional volatile organic compound contamination and the northern part is within the capture zone of the 200-ZP-1 interim action pump-and-treat remediation system. Carbon tetrachloride is the major contaminant in the plume but chloroform, trichloroethene, and tetrachloroethene are also present. Nitrate contamination is also found. 


\subsection{Conceptual Model}

This section describes a conceptual model for potential contaminant transport to guide future groundwater monitoring. The scenarios for contaminant release and transport are based on the following assumptions:

- Engineered barriers are not taken into account, so the model is applicable to unlined trenches but is highly conservative for the newest (lined) mixed waste trenches.

- Only the operational period is considered (i.e., current cover materials are considered, not final covers; retrievable waste assumed to still be in place).

- Average precipitation and net infiltration (10 centimeters per year) prevails over the time period of interest.

- Preferential pathways, if present, are assumed to have little if any influence on the average net flux of contaminants reaching groundwater.

- Leaching of mobile contaminants from buried waste in unsealed containers, or contaminated soils in direct contact with the trench, is assumed to occur at a constant rate beginning at the time of placement.

- There are no artificial sources of water (e.g., leaking potable or raw water lines based on Hanford drawings).

\subsubsection{Geochemical Considerations}

The leachability and subsequent mobility of waste constituents in pore fluid are dependent on the container, chemical nature of the waste constituents, and natural subsurface geochemical conditions.

Pore fluid in the unsaturated and saturated zones beneath the 200 Areas is slightly alkaline $(\mathrm{pH}>8)$ with appreciable amounts of bicarbonate $\left(\mathrm{HCO}_{3}{ }^{-}\right)$and very little natural organic material. The lack of organic matter means that conditions are generally oxidizing. Calcium carbonate also is abundant in vadose zone sediment. Based on the general geochemical conditions noted above, the chemistry of the waste constituents and observations made under Hanford conditions, the cationic constituents are not expected to be very mobile due to sorption or retardation unless anionic complexes or oxyanions are formed in solution. For example, hexavalent chromium is more mobile in groundwater than trivalent chromium due to the formation of the chromate ion $\left(\mathrm{CrO}_{4}^{-2}\right)$. The anionic constituents are expected to be mobile in pore fluid and are assumed, in the worst case, to travel relatively unhindered in vadose zone moisture that drains to the water table.

\subsubsection{Vadose Zone Transport and Minimum Travel Time}

Direct precipitation is the primary driver for hypothetical leaching of waste constituents from the burial trenches and subsequent transport to groundwater because free liquids are believed to be negligible 
in most waste forms. Contaminated soil in direct contact with the trench or waste in degradable containers (cardboard boxes or wooden boxes subject to collapse) is assumed to be leachable. It addition, volatile organic constituents have the potential to move toward the water table through vapor-phase transport.

The amount of natural infiltration that can pass through the leachable buried waste and drain to the water table is controlled by the texture of the cover and backfill and the degree of vegetative cover. Stratigraphic features in the soil column beneath the buried waste can also influence or retard downward migration by spreading soil moisture laterally. Direct observational evidence to assess this effect in each burial ground is lacking. Thus, this conceptual model does not account for lateral spreading.

Most of the burial ground trenches are backfilled with the natural excavation materials (Hanford formation) consisting of coarse gravel, cobbles, and some interstitial sand. Sparse amounts of native vegetation appear on the established backfilled areas and on the unused portion. A coarse, unvegetated cover material allows a major fraction of the precipitation to infiltrate and potentially drain to groundwater. $\mathrm{Gee}^{2}$ estimates that in the 200-West Area drainage beneath a coarse cover can be as high as 10 centimeters per year. Under such conditions the average rate of water movement through the vadose zone could be as high as 2 meters per year.

The presence of fine-grained sediment and the occurrence of vegetation over the burial grounds can significantly reduce the net drainage due to enhanced evapotranspiration. In these cases, the net drainage could be an order of magnitude less than the maximum indicated above. However, direct observations of drainage are lacking at the burial grounds. Vertical moisture profiles would be needed at key locations before any credit could be taken for enhanced evapotranspiration. Thus, for purposes of this monitoring plan, the maximum infiltration and moisture migration rates are assumed.

If water movement in the vadose zone at the 200-East Area LLWMA-1 and LLWMA-2 averaged 2 meters per year, the minimum travel time to reach groundwater would be $\sim 40$ years for the most mobile contaminants. Minimum travel times in 200-West Area LLWMA-3 and LLWMA-4 is slightly lower, $\sim 35$ years. However, the presence of the plieo-pleistocene layer in the subsurface of 200-West Area likely retards downward movement of moisture and contaminants. In addition, a cemented zone near the water table will act as a barrier to vadose zone transport where it is located above the water table. Other textural changes in the sediments will provide capillary breaks and inhibit moisture movement.

\subsubsection{Constituents of Potential Concern for Groundwater Monitoring}

Monitoring of certain constituents is required during detection monitoring under RCRA regulations, as discussed in Chapter 3. Other constituents will also be monitored under this plan, if they are considered to be possible indicators of site impacts, provide additional information for interpreting groundwater chemistry, or provide continuity with previous interim status monitoring. These constituents are discussed in the following paragraphs.

The presence of dissolved chromium in groundwater may indicate an impact from the LLWMAs. However, there is some chromium associated with upgradient sources and with the use of stainless steel

\footnotetext{
${ }^{2}$ Gee, Glendon (PNNL, Richland, Washington) personal communication with Vernon Johnson, February 2002.
} 
in monitoring wells and well pumps. Thus, any chromium detection must be considered in context of the surrounding conditions. Chromium and other metal samples will be filtered because dissolved and sub$0.45 \mu \mathrm{m}$ particles provide a reasonable measurement of the mobile metal fraction. In addition, stainless steel well construction at the LLWMAs biases unfiltered metal samples. Sodium, iron, and manganese are required groundwater quality parameters. Other metals will support the chromium and major ion analysis of groundwater. The most important additional metal constituents are calcium, magnesium, potassium, and nickel.

Nitrate is a ubiquitous Hanford Site groundwater contaminant that may be present in the burial grounds. It is highly mobile as an anion in groundwater under site conditions. Sulfate and chloride are required groundwater quality parameters that are also a potential site contaminant found as anions. Nitrite is an additional anion that supports the interpretation of nitrate and general groundwater quality.

Extensive volatile organic contamination is present in 200-West Area groundwater, with carbon tetrachloride being the major concern. Chloroform, trichloroethene, and tetrachloroethene are also detected. These constituents may have been disposed to the 200-West Area burial grounds along with toluene and xylene. Benzene and ethylbenzene, components of petroleum hydrocarbons that commonly contaminate groundwater, will also be included in volatile organic analyses. Additional constituents may also be reported, depending on laboratory contractual arrangements. Volatile organic compounds will only be included for analysis at LLWMA-3 and LLWMA-4 in the 200-West Area because they are generally not seen as groundwater contaminants in the 200-East Area. Required analysis of total organic carbon and total organic halides will provide some screening information on these and other organic contaminants in the 200-East Area.

Analysis of alkalinity supports the characterization of general groundwater quality because it allows the calculation of charge balance for samples with metal and anion analyses. Turbidity, temperature, and dissolved oxygen are field measurements that support data interpretation.

Lead and mercury likely were disposed to the LLWMAs in the past but are not considered mobile under site conditions. Monitoring of these species was specified in the previous monitoring plan and will be continued for at least a year after implementation of this plan to maintain continuity. However, due to the lack of indication of impacts from these constituents, frequency will be reduced to annual.

Polychlorinated biphenyls (PCBs) are present in the encapsulated naval reactor compartments disposed in LLWMA-2. However, all drainable liquid PCB has been removed from the compartments, sorbent added and the compartments form special high-integrity containers designed not to fail until long past expected post-closure care is terminated. Polychlorinated biphenyls are strongly sorbed to sediments and are not seen as a groundwater risk. Monitoring of these compounds will continue for at least a year after implementation of this plan to maintain continuity with previous monitoring but frequency will be reduced to annual. The PCBs are regulated under the Toxic Substances Control Act (TSCA). 


\subsection{Groundwater Monitoring Program}

This section presents an overview of the components of groundwater monitoring for RCRA monitoring of the LLWMAs. The complete list of wells, constituents of interest, sampling requirements, and analytical methods for sampling at each LLWMA are tabulated in Appendix A, Sampling and Analysis Plan.

\subsection{Constituent List and Sampling Frequency}

Wells will be sampled semi-annually for indicators of groundwater contamination $\mathrm{pH}$, specific conductance, total organic carbon, and total organic halides (total organic halogen) as required by 40 CFR 265.92. Four replicate measurements will be made for each indicator parameter sample.

Wells will be sampled semi-annually for groundwater quality parameters, chloride, iron, manganese, sodium, sulfate, and annually for phenols. Annual analysis is the minimum required for these parameters under 40 CFR 265.92. Several metals and anions indicative of known Hanford Site contamination are also reported by the multi-constituent analytical methods used for analysis of the groundwater quality parameters so semi-annual sampling is warranted.

Several site-specific constituents will be monitored semi-annually or annually in addition to the parameters required under the RCRA regulations. These parameters are based on the site conceptual model (Section 3.0) and continuity with previous monitoring. The site-specific parameters are defined separately for each LLWMA. Several constituents are included to provide a more complete description of water quality and quality control. Additional constituents may be included if they are part of a multiconstituent analytical method, to address issues at specific wells, or as specified per ICN (see Section 1.2).

\subsubsection{Differences from Previous Monitoring}

Monitoring frequency for alkalinity, lead, mercury, and PCBs is being reduced (see Appendix A). Dissolved oxygen was added as a field measurement to provide an indication of oxidation state in the aquifer.

\subsection{Monitoring Well Network}

Detection monitoring at the LLWMAs is hindered by gaps in the well network. Many of the wells previously monitored as part of the RCRA monitoring systems at LLWMA-2, LLWMA-3, and LLWMA-4 have gone dry due to regional declines in water levels. At LLWMA-2, the water table has declined below the top of the basalt so replacement wells are not practical. The schedule for installation of new monitoring wells across the site is set out in TPA Milestone M-24. This milestone is re-assessed annually. Seventeen new wells for LLWMA-3 and LLWMA-4 are currently planned for fiscal years 2005 and 2006. The 17 new wells are listed in this plan and will be scheduled for sampling after each drilling campaign. Well location maps are included in the Sampling and Analysis Plan (Appendix A). 
Tables listing monitoring wells to be sampled are included in the Sampling and Analysis Plan (Appendix A). Several wells in the monitoring network are expected to go dry in the next several years. Wells will be deleted from the monitoring network, using the ICN process as they go dry (see Section 1.2).

Some wells in the monitoring network provide supplemental data and are not designed to be included in the statistical detection monitoring. Samples of contaminant indicator parameters from these wells will not be collected in quadruplicate for statistical comparisons. The contaminant indicator parameters are discussed in Section 4.2. The supplemental wells include LLWMA-2 well 299-E34-5, which is believed

to be hydraulically isolated from the rest of the waste management area by the basalt surface; LLWMA-3 deep unconfined aquifer wells 299-W7-3 and 299-W10-14; and LLWMA-4 deep unconfined aquifer wells 299-W15-17 and 299-W18-22.

\subsubsection{Differences from Previous Monitoring}

Well 299-W15-16 is a downgradient well at LLWMA-4 that has gone dry due to declining water levels. Well 299-W15-30 was installed approximately 15 meters north of well 299-W15-16 as an extraction well but is not being used for that purpose.

\subsubsection{New Wells}

Thirteen new wells have been identified for installation at LLWMA-3 (Byrnes and Williams 2003). Of these, eight have been prioritized with installation anticipated for fiscal years 2005 and 2006. The priority of the four other wells will be determined in future TPA Milestone M-24 negotiations. Proposed well locations at LLWMA-3 are shown in Figure 3.1. Assuming the four wells are installed while this plan is still in effect, they will be added to the sampling schedule for the semi-annual sampling event after the wells are ready for sampling.

Ten new wells have been identified for installation at LLWMA-4 (Byrnes and Williams 2003). Of these, nine have been prioritized along with wells at LLWMA-3 and installation is anticipated during fiscal year 2005 and 2006. The priority of the tenth well will be determined in future TPA Milestone M-24 negotiations. Proposed well locations at LLWMA-4 are shown in Figure 3.2. The new wells will be added to the sampling schedule for the semi-annual sampling event after the drilling campaign is complete (i.e. after the nine prioritized wells are ready for sampling). Assuming the tenth well is installed while this plan is still in effect, it will be added to the sampling schedule for the semi-annual sampling event after it is ready for sampling.

Any other wells are identified as being needed at the LLWMAs will be prioritized through the TPA Milestone M-24 process. The wells would be added to this plan through an ICN after they are ready to be sampled. 


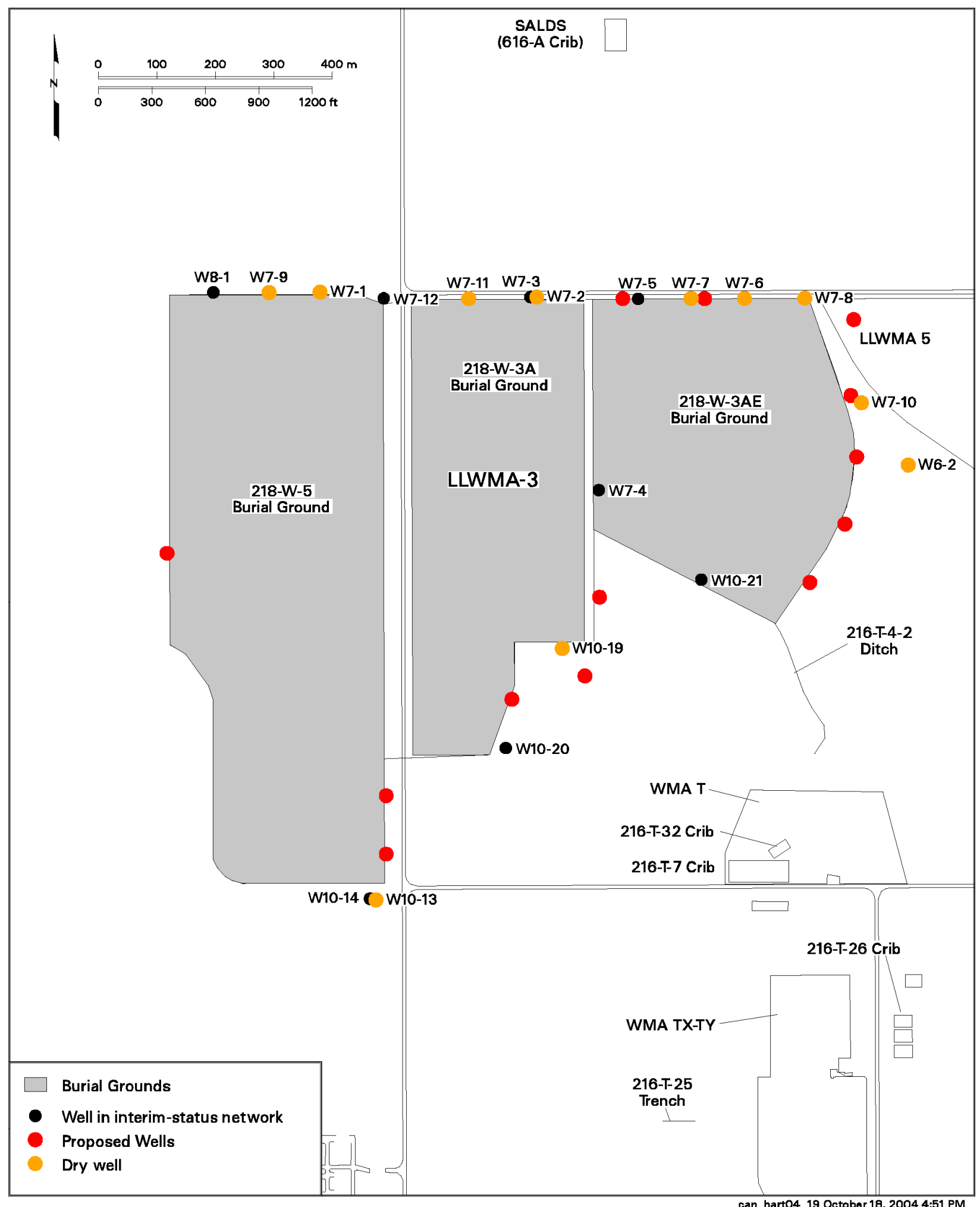

Figure 3.1. Locations for Proposed New Wells at LLWMA-3 


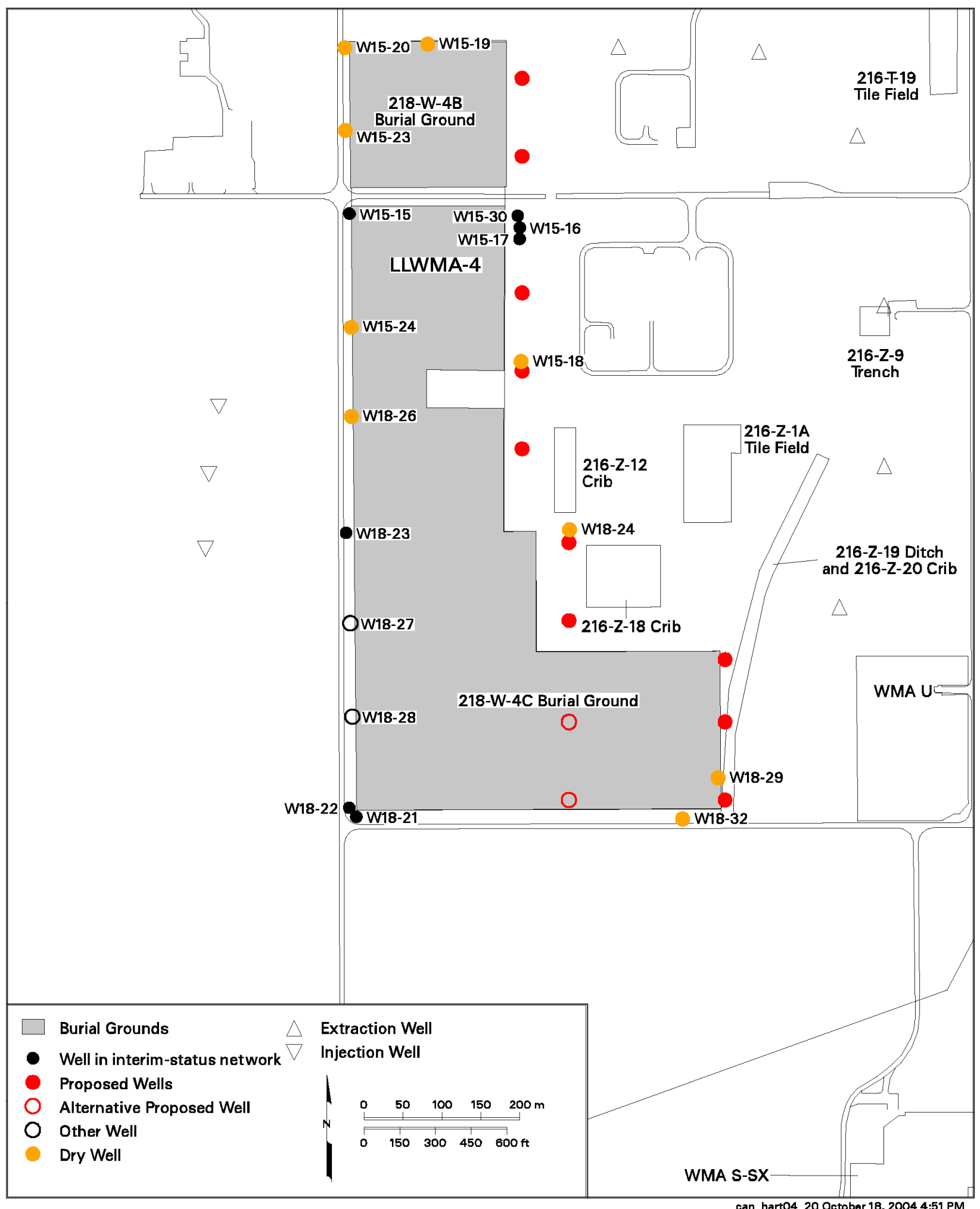

Figure 3.2. Locations for Proposed New Wells at LLWMA-4 
Any other wells are identified as being needed at the LLWMAs will be prioritized through the TPA Milestone M-24 process. The wells would be added to this plan through an ICN after they are ready to be sampled.

\subsection{Sampling and Analysis Protocol}

RCRA groundwater monitoring for the LLBGs is part of the Hanford Site Groundwater Performance Assessment Project (groundwater project). This section describes the groundwater project's protocols for sample collection and analysis. RCRA groundwater monitoring for the LLBGs is part of the groundwater project and follows the project's quality assurance plan. Groundwater monitoring for LLBG will follow the requirements of the most recent revision of the quality assurance project plan; this monitoring plan need not be revised to cite future revisions of the quality assurance plan.

Project staff schedule sampling and initiate paperwork. The project uses subcontractors for sample collection, shipping, and analysis. Quality requirements for the subcontracted work are specified in statements of work or contracts.

The statement of work for sampling activities specifies that activities shall be in accordance with a quality assurance project plan that meets the requirements defined in EPA (2001). Additional requirements are specified in the statement of work.

Groundwater project staff conduct laboratory audits and field surveillances to assess the quality of subcontracted work and initiate corrective action if needed.

\subsubsection{Scheduling Groundwater Sampling}

The groundwater project schedules well sampling. Many Hanford Site wells are sampled for multiple objectives and requirements, e.g., RCRA, CERCLA, AEA. Scheduling activities help manage the overlap, eliminating redundant sampling and meeting the needs of each sampling objective. Scheduling activities include the following:

- Each fiscal year, project scientists provide well lists, constituent lists, and sampling frequency. Each month, project scientists review the sampling schedule for the following month. Changes are requested via change request forms and approved by the sampling and analysis task lead and the monitoring project manager.

- Project staff track sampling and analysis through an electronic schedule database, stored on a server at Pacific Northwest National Laboratory (PNNL). Quality control samples also are managed through this database. A scheduling program generates unique sample numbers and a special user interface generates sample authorization forms, field services reports, groundwater sample report forms, chain-of-custody forms, and sample container labels.

- Sampling and analysis staff verify that well name, sample numbers, bottle sizes, preservatives, etc. are indicated properly on the paperwork, which is transmitted to the sampling subcontractor. Staff complete a checklist to document that the paperwork was generated correctly. 
- At each month's end, project staff use the schedule database to determine if any wells were not sampled as scheduled. If the wells or sampling pumps require maintenance, they are rescheduled following repair. If a well can no longer be sampled, it is cancelled and the reason is recorded in the database. DOE will notify Ecology if sampling is delayed past the end of the scheduled quarter or if a well cannot be sampled.

\subsubsection{Chain of Custody}

The sampling subcontractor uses chain-of-custody forms to document the integrity of groundwater samples from the time of collection through data reporting. The forms are generated during scheduling and managed through subcontractor procedures.

\subsubsection{Sample Collection}

The procedure for groundwater sampling is described in subcontractor procedures. Data collected during sampling of each well are recorded on groundwater sample report forms. Samples generally are collected after three casing volumes of water have been purged from the well and after field parameters ( $\mathrm{pH}$, temperature, specific conductance, and turbidity) have stabilized (i.e., after two consecutive measurements are within 0.2 units $\mathrm{pH}, 0.2^{\circ} \mathrm{C}$ for temperature, $10 \%$ for specific conductance, and turbidity $<5$ Nephelometric Turbidity Units (NTU). For routine groundwater samples, preservatives are added to the collection bottles before their use in the field according to subcontractor procedures. Samples to be analyzed for metals are usually filtered in the field so that results represent dissolved metals.

\subsubsection{Analytical Protocols}

Procedures for required field measurements are specified in subcontractor procedures. Each instrument is assigned a unique number that is tracked on field documentation and is calibrated and controlled according to subcontractor procedures. Additional calibration and use instructions are specified in the instrument user manuals.

Laboratory analytical methods are specified in contracts with the laboratories, and most are standard methods from Test Methods for Evaluating Solid Wastes, Physical/Chemical Methods (EPA 1986) or Methods for Chemical Analysis of Water and Wastes (EPA 1979). 


\subsection{Quality Assurance}

The groundwater project's quality assurance plan is compliant with EPA Requirements for Quality Assurance Project Plans (EPA 2001). A quality control plan is included in the groundwater project quality assurance plan, and quality control sampling requirements for subcontracted work are discussed in the statement of work.

The groundwater project's quality control program is designed to assess and enhance the reliability and validity of groundwater data. This is accomplished through evaluating the results of quality control samples, conducting audits, and validating groundwater data. This section describes the quality control program for the entire groundwater project, which includes the LLWMAs.

The quality control practices of the groundwater project are based on the Tri-Party Agreement Action Plan, Section 6.5 (Ecology et al. 1998). Accuracy, precision, and detection are the primary parameters used to assess data quality (Mitchell et al. 1985). Data for these parameters are obtained from two categories of quality control samples: those that provide checks on field and laboratory activities (field quality control) and those that monitor laboratory performance (laboratory quality control). Table 4.1 summarizes the types of samples in each category and the sample frequencies and characteristics evaluated.

\subsection{Quality Control Criteria}

Quality control data are evaluated based on established acceptance criteria for each quality control sample type. For field and method blanks, the acceptance limit is generally two times the instrument detection limit (metals), method detection limit (other chemical parameters), or minimum detectable activity (radiochemistry parameters). However, for common laboratory contaminants such as acetone, methylene chloride, 2-butanone, and phthalate esters, the limit is five times the method detection limit. Groundwater samples that are associated (i.e., collected on the same date and analyzed by the same method) with out-of-limit field blanks are flagged with a $\mathrm{Q}$ in the database to indicate a potential contamination problem.

Field duplicates must agree within $20 \%$, as measured by the relative percent difference (RPD), to be acceptable. Only those field duplicates with at least one result greater than five times the appropriate detection limit are evaluated. Unacceptable field duplicate results are also flagged with a $\mathrm{Q}$ in the database.

The acceptance criteria for laboratory duplicates, matrix spikes, matrix spike duplicates, surrogates, and laboratory control samples are generally derived from historical data at the laboratories in accordance with Test Methods for Evaluating Solid Wastes, Physical/Chemical Methods (EPA 1986). Typical acceptance limits are within $25 \%$ of the expected values, although the limits may vary considerably with the method and analyte. Current values for laboratory duplicates, matrix spikes, and laboratory control samples are $20 \%$ RPD, $60 \%-140 \%$, and $70 \%-130 \%$, respectively. These values are subject to change if the contract is modified or replaced. 
Table 4.1. Quality Control Samples

\begin{tabular}{|c|c|c|}
\hline Sample Type & Primary Characteristics Evaluated & Frequency \\
\hline \multicolumn{3}{|c|}{ Field Quality Control } \\
\hline Full Trip Blank & $\begin{array}{l}\text { Contamination from containers or } \\
\text { transportation }\end{array}$ & 1 per 20 well trips \\
\hline Field Transfer Blank & $\begin{array}{l}\text { Airborne contamination from the } \\
\text { sampling site }\end{array}$ & $\begin{array}{l}1 \text { each day volatile organic } \\
\text { compound samples are } \\
\text { collected }\end{array}$ \\
\hline Equipment Blank & $\begin{array}{l}\text { Contamination from non-dedicated } \\
\text { sampling equipment }\end{array}$ & $\begin{array}{l}1 \text { per } 10 \text { well trips where non- } \\
\text { dedicated equipment is used }{ }^{\text {(a) }}\end{array}$ \\
\hline Duplicate Samples & Reproducibility & 1 per 20 well trips \\
\hline \multicolumn{3}{|c|}{ Laboratory Quality Control } \\
\hline Method Blank & Laboratory contamination & 1 per batch \\
\hline Lab Duplicates & Laboratory reproducibility & Method/contract specific ${ }^{(b)}$ \\
\hline Matrix Spike & Matrix effects and laboratory accuracy & Method/contract specific ${ }^{(b)}$ \\
\hline Matrix Spike Duplicate & Laboratory reproducibility and accuracy & Method/contract specific ${ }^{(b)}$ \\
\hline Surrogates & Recovery/yield & Method/contract specific ${ }^{(b)}$ \\
\hline Laboratory Control Sample & Accuracy & 1 per batch \\
\hline Double Blind Standards & Accuracy and precision & Varies by constituent ${ }^{(\mathrm{c})}$ \\
\hline \multicolumn{3}{|c|}{ (b) If called for by the analytical method, duplicates, matrix spikes, and matrix spike duplicates are } \\
\hline \multicolumn{3}{|c|}{$\begin{array}{l}\text { (c) Double blind standards containing known concentrations of selected analytes are typically submitted in } \\
\text { triplicate or quadruplicate on a quarterly, semi-annual, or annual basis. }\end{array}$} \\
\hline
\end{tabular}

Table 4.2 lists the acceptable recovery limits for the double blind standards. These samples are prepared by spiking background well water (currently wells 699-19-88 and 699-49-100C) with known concentrations of constituents of interest. Spiking concentrations range from the detection limit to the upper limit of concentration determined in groundwater on the Hanford site. Double blind standard results that are outside the acceptance limits are investigated and appropriate actions are taken if necessary.

Holding time is the elapsed time period between sample collection and analysis. Exceeding recommended holding times could result in changes in constituent concentrations due to volatilization, decomposition, or other chemical alterations. Recommended holding times depend on the analytical method, as specified in Test Methods for Evaluating Solid Wastes, Physical/Chemical Methods (EPA 1986) or Methods for Chemical Analysis of Water and Wastes (EPA 1979). Holding times are specified in laboratory contracts. Data associated with exceeded holding times are flagged with an " $\mathrm{H}$ " in the Hanford Environmental Information System (HEIS) database. 
Table 4.2. Recovery Limits for Double Blind Standards

\begin{tabular}{|c|c|c|c|}
\hline Constituent & Frequency & Recovery Limits & Precision Limits (RSD) \\
\hline Specific conductance & Quarterly & $75-125 \%$ & $25 \%$ \\
\hline Total organic carbon ${ }^{(\mathrm{a})}$ & Quarterly & $75-125 \%$ & Varies with spiking compound \\
\hline Total organic halides ${ }^{(b)}$ & Quarterly & $75-125 \%$ & Varies with spiking compound \\
\hline Nitrate & Quarterly & $75-125 \%$ & $25 \%$ \\
\hline Chromium & Annually & $80-120 \%$ & $20 \%$ \\
\hline Carbon tetrachloride & Quarterly & $75-125 \%$ & $25 \%$ \\
\hline Chloroform & Quarterly & $75-125 \%$ & $25 \%$ \\
\hline Trichloroethene & Quarterly & $75-125 \%$ & $25 \%$ \\
\hline \multicolumn{4}{|c|}{$\begin{array}{l}\text { (a) The spiking compound generally used for total organic carbon is potassium hydrogen phthala } \\
\text { spiking compounds may also be used. } \\
\text { (b) Two sets of spikes for total organic halides will be used. The first should be prepared with } \\
2,4,5 \text {-trichlorophenol. The second set will be spiked with a mixture of carbon tetrachloride, } \\
\text { chloroform, and trichloroethene. } \\
\text { RSD = Relative standard deviation. }\end{array}$} \\
\hline
\end{tabular}

Additional quality control measures include laboratory audits and participation in nationally based performance evaluation studies. The contract laboratories participate in national studies such as the EPAsanctioned Water Pollution and Water Supply Performance Evaluation studies. The groundwater project periodically audits the analytical laboratories to identify and solve quality problems, or to prevent such problems. Audit results are used to improve performance. Summaries of audit results and performance evaluation studies are presented in the annual groundwater monitoring report.

\subsection{Groundwater Data Validation Process}

The groundwater project's data validation process provides requirements and guidance for validation of groundwater data that are routinely collected as part of the groundwater project. Validation is a systematic process of reviewing data against a set of criteria to determine whether the data are acceptable for their intended use. This process applies to groundwater data that have been verified (see Section 5.1) and loaded into HEIS. The outcome of the activities described below is an electronic data set with suspect or erroneous data corrected or flagged. Groundwater monitoring project staff document the validation process quarterly by signing a checklist, which is stored in the project file.

Responsibilities for data validation are divided among project staff. Each RCRA unit or geographic region is assigned to a project scientist, who is familiar with the hydrogeologic conditions of that site. The data validation process includes the following elements:

- Generation of data reports. Twice each month, data management staff provide tables of newly loaded data to project scientists for evaluation (biweekly reports). Also, after laboratory results from a reporting quarter have been loaded into HEIS, staff produce tables of water-level data and 
analytical data for wells sampled within that quarter (quarterly reports). The quarterly data reports include any data flags added during the quality control evaluation or as a result of prior data review.

- Project scientist evaluation. As soon as practical after receiving biweekly reports, project scientists review the data to identify changes in groundwater quality or potential data errors. Evaluation techniques include comparing key constituents to historical trends or spatial patterns. Other data checks may include comparison of general parameters to their specific counterparts (e.g., conductivity to ions) and calculation of charge balances. Project scientists request data reviews if appropriate (see Section 5.2). If necessary, the lab may be asked to check calculations or reanalyze the sample, or the well may be resampled. After receiving quarterly reports, project scientists review sampling summary tables to determine whether network wells were sampled and analyzed as scheduled. If not, they work with other project staff to resolve the problem. Project scientists also review quarterly reports of analytical and water-level data using the same techniques as for biweekly reports. Unlike the biweekly reports, the quarterly reports usually include a full data set (i.e., all the data from the wells sampled during the previous quarter have been received and loaded into HEIS).

- Quality control reports. Staff report results of quality control evaluations informally to project staff, DOE-RL, and Ecology each quarter. Results for each fiscal year are described in the annual groundwater monitoring report. 


\subsection{Data Management, Evaluation, and Reporting}

This section describes how groundwater data are stored, retrieved, and interpreted.

\subsection{Loading and Verifying Data}

The contract laboratories report analytical results electronically and in hard copy. The electronic results are loaded into HEIS. Hard copy data reports and field records are considered to be the record copies and are stored at PNNL. Project staff perform an array of computer checks on the electronic file for formatting, allowed values, data flagging (qualifiers), and completeness. Verification of the hard copy results includes checks for (1) completeness, (2) notes on condition of samples upon receipt by the laboratory, (3) notes on problems that arose during the analysis of the samples, and (4) correct reporting of results. If data are incomplete or deficient, staff work with the laboratory to get the problems corrected. Notes on condition of samples or problems during analysis may be used to support data reviews (see Section 5.2).

Field data such as specific conductance, $\mathrm{pH}$, temperature, turbidity, and depth-to-water, are recorded on field records. Data management staff enter these into HEIS manually through data-entry screens, verify each value against the hard copy, and initial each value on the hard copy.

\subsection{Data Review}

The groundwater project conducts special reviews of groundwater analytical data or field measurements when results are in question. Groundwater project staff document the process on a review form and results are used to flag the data appropriately in HEIS. Various staff may initiate a review form, e.g., project scientists, data management, and quality control.

Typical data review actions may include rechecking laboratory calculations and records, recounting radiochemical samples, re-analyzing samples, or simply flagging data as suspect in the HEIS database.

\subsection{Statistical Evaluation}

Statistical upgradient-downgradient comparisons are required to test for potential impacts to groundwater at RCRA interim-status monitoring facilities (40 CFR 265.93). For each of the four indicator parameters, the owner or operator must calculate the arithmetic mean and variance, based on at least four replicate measurements on each sample, for each well monitored and compare these results with its initial background arithmetic mean. The comparison must consider individually each of the wells in the monitoring system, and must use the Student's t-test at the 0.01 level of significance to determine statistically significant increases (and decreases in the case of $\mathrm{pH}$ ) over initial background.

The implementation of the statistical test method at the Hanford Site, including the LLWMAs is described in more detail in Hartman (2000) and Chou (1991). If the statistical critical mean comparison value calculated from upgradient wells is lower than the detection limit, then the detection limit is used as 
the statistical comparison value. This typically occurs for total organic carbon and total organic halides at LLWMA-1 and total organic halides at LLWMA-2. Statistical comparison values may be updated periodically due to changes in upgradient conditions, changes in flow direction, or changes in detection limits.

If comparisons for upgradient wells show a significant increase (or $\mathrm{pH}$ decrease), the information must be submitted in the Hanford Site annual report (see Section 6.5). If the comparisons for a downgradient well show a significant increase (or $\mathrm{pH}$ decrease), then the well is re-sampled and split samples are sent to different laboratories to determine if the exceedance of the comparison value was the result of laboratory error. In addition, the original samples may be re-analyzed if laboratory error is suspected.

If the exceedance of the statistical comparison value is confirmed by the re-sampling, then written notice is provided to the regional administrator within seven days that the facility may be affecting groundwater quality. Within 15 days after the notification, a groundwater quality assessment program must be developed and submitted. In some instances, it is possible to determine immediately that the statistical finding is not the result of contamination from the facility. In that case, the regional administrator is notified and an assessment program is not instituted.

Flow direction changes at LLWMA-3 that have occurred in recent years necessitate the reclassification of upgradient and downgradient wells. Monitoring wells 299-W10-20 and 299-W10-21 were formerly categorized as upgradient wells but are currently downgradient of parts of the LLWMA. These wells are included as downgradient wells in this plan, although they continue to be affected by contamination from upgradient sources. Statistical comparisons will be suspended until a new background well or wells are installed under the TPA Milestone M-24 process and background values are re-established. As discussed in Section 2.3.3.3, however, it is likely that upgradient wells along the west side of LLWMA-3 will have lower levels of contaminants from regional plumes than the downgradient wells further east since the contamination moved into the area from the south. Thus, exceedances of statistical comparison values can be expected until the regional plumes migrate downgradient.

\subsection{Interpretation}

After data are validated and verified, the acceptable data are used to interpret groundwater conditions at the site. Interpretive techniques include:

- Hydrographs - graph water levels vs. time to determine decreases, increases, seasonal, or man-made fluctuations in groundwater levels.

- Water-table maps - use water-table elevations from multiple wells to construct contour maps to estimate flow directions. Groundwater flow is assumed to be perpendicular to lines of equal potential.

- Trend plots - graph concentrations of chemical or radiological constituents vs. time to determine increases, decreases, and fluctuations. May be used in tandem with hydrographs and/or water-table maps to determine if concentrations relate to changes in water level or in groundwater flow directions. 
- Plume maps - map distributions of chemical constituents are in the aquifer to determine extent of contamination. Changes in plume distribution over time aid in determining movement of plumes and direction of flow.

- Contaminant ratios - can sometimes be used to distinguish between different sources of contamination.

\subsection{Reporting}

Reporting requirements for sites in interim detection status are fulfilled through the groundwater project's existing reports (e.g., RCRA quarterly reports submitted via e-mail, and annual reports issued in March [e.g., Hartman et al. 2004]). Chemistry and water-level data are reviewed after each sampling event and are available in HEIS.

If the exceedance of the statistical comparison value is confirmed by the re-sampling, then written notice is provided to the regional administrator within seven days that the facility may be affecting groundwater quality. Within 15 days after the notification, a groundwater quality assessment program must be developed and submitted. In some instances, it is possible to determine immediately that the statistical finding is not the result of contamination from the facility. In that case, the regional administrator is notified and an assessment program is not instituted. 


\subsection{References}

40 CFR 265. "Interim Status Standards for Owners and Operators of Hazardous Waste Treatment, Storage, and Disposal Facilities." Code of Federal Regulations, U.S. Environmental Protection Agency.

40 CFR 265, Subpart F. “Ground-Water Monitoring.” Code of Federal Regulations, U.S. Environmental Protection Agency.

40 CFR 265.92. "Sampling and Analysis." Code of Federal Regulations, U.S. Environmental Protection Agency.

40 CFR 265.93. "Preparation, Evaluation, and Response.” Code of Federal Regulations, U.S. Environmental Protection Agency.

Atomic Energy Act of 1954. As amended, Ch. 1073, 68 Stat. 919, 42 USC 2011 et seq.

Byrnes ME and BA Williams. 2003. Data Quality Objective Summary Report for Establishing a RCRA/ CERCLA/AEA Integrated 200 West and 200 East Area Groundwater Monitoring Network. CP-15329, Rev. 0, prepared by Fluor Hanford, Inc. and Pacific Northwest National Laboratory for the U.S. Department of Energy, Richland, Washington.

Chamness MA, EJ Jensen, and GV Last. 1990. Interim-Status Ground-Water Quality Assessment Monitoring Plan for Waste Management Area 3 of the 200 Areas Low-Level Burial Grounds. WHC-SD-ENAP-022, Westinghouse Hanford Company, Richland, Washington.

Chou, CJ. 1991. Statistical Approach on RCRA Groundwater Monitoring Projects at the Hanford Site. In American Statistical Association 1991 Proceedings of the Section on Statistics and the Environment. Alexandria Virginia; also, WHC-SA-1124-FP, Westinghouse Hanford Company, Richland, Washington.

Comprehensive Environmental Response, Compensation, and Liability Act. 1980. Public Law 96-510, as amended, 94 Stat. 2767, 42 USC 9601 et seq.

DOE. 2000. Performance Assessment Monitoring Plan for the Hanford Site Low-Level Burial Grounds. DOE/RL-2000-72, Rev 0, U.S. Department of Energy, Richland, Washington.

DOE Order 435.1. 1999. Radioactive Waste Management. U.S. Department of Energy, Washington, D.C. Available on the Internet at: http://www.hanford.gov/wastemgt/doe/psg/pdf/doeo435.1.pdf

Ecology - Washington State Department of Ecology, U.S. Environmental Protection Agency, and U.S. Department of Energy. 1989. Hanford Federal Facility Agreement and Consent Order. Document No. 89-10, as amended (The Tri-Party Agreement), Olympia, Washington. 
Ecology - Washington State Department of Ecology. 1994, as amended. Dangerous Waste Portion of the Resource Conservation and Recovery Act Permit for the Treatment, Storage, and Disposal of Dangerous Waste. Permit Number WA7890008967, effective September 28, 1994, Washington State Department of Ecology, Olympia, Washington.

EPA. 1979. Methods for Chemical Analysis of Water and Wastes. EPA-600/4-79-020, U.S. Environmental Protection Agency, Washington, D.C.

EPA. 1986. Test Methods for Evaluating Solid Waste: Physical/Chemical Methods, SW-846, Third Edition. Office of Solid Waste and Emergency Response, U.S. Environmental Protection Agency, Washington, D.C. Available online at: http://www.epa.gov/epaoswer/hazwaste/test/sw846.htm

EPA. 2001, as revised. EPA Requirements for Quality Assurance Project Plans. EPA/240/B-01/003/ (QA/R-5), U.S. Environmental Protection Agency, Washington, D.C.

Hartman MJ (ed). 2000. Hanford Site Groundwater Monitoring: Setting, Sources, and Methods. PNNL-13080, Pacific Northwest National Laboratory, Richland, Washington.

Hartman MJ, LF Morasch, and WD Webber (eds.). 2004. Hanford Site Groundwater Monitoring for Fiscal Year 2003. PNNL-14548, Pacific Northwest National Laboratory, Richland, Washington.

Last GV and BN Bjornstad. 1989. Revised Ground-Water Monitoring Plan for the 200 Areas Low-Level Burial Grounds. WHC-SD-EN-AP-015, Rev. 0, Westinghouse Hanford Company, Richland, Washington.

Mercer RB. 1993a. Results of Groundwater Quality Assessment Program at Low-Level Waste Management Area 1 of the Low-Level Burial Grounds. WHC-SD-EN-EV-025, Rev. 0, Westinghouse Hanford Company, Richland, Washington.

Mercer, RB. 1993b. Results of Groundwater Quality Assessment Program at Low-Level Waste Management Area 3 of the Low-Level Burial Grounds. WHC-SD-EN-EV-026, Rev. 0, Westinghouse Hanford Company, Richland, Washington.

Mitchell WJ, RC Rhodes, and FF McElroy. 1985. "Determination of Measurement Data Quality and Establishment of Achievable Goals for Environmental Measurements." In Quality Assurance for Environmental Measurements, ASTM STP 867, American Society for Testing and Materials, West Conshohocken, Pennsylvania.

NAVD88. 1988. North American Vertical Datum of 1988.

Resource Conservation and Recovery Act. 1976. Public Law 94-580, as amended, 90 Stat. 2795, 42 USC 6901 et seq.

Toxic Substances Control Act. 1976. Public Law 94-469, as amended, 90 Stat. 2003, 15 USC 2601 et seq. 
WAC 173-303. "Dangerous Waste Regulations.” Washington Administrative Code, Olympia, Washington.

WAC 173-303-400. "Interim Status Facility Standards." Washington Administrative Code, Olympia, Washington.

Williams, BA, BN Bjornstad, R Schalla, and WD Webber. 2000. Revised Hydrogeology for the Suprabasalt Upper Aquifer System, 200 East Area, Hanford Site, Washington. PNNL-12261, Pacific Northwest National Laboratory, Richland, Washington.

Williams BA, BN Bjornstad, R Schalla, and WD Webber. 2002. Revised Hydrogeology for the Suprabasalt Aquifer System, 200-West Area and Vicinity, Hanford Site, Washington. PNNL-13858, Pacific Northwest National Laboratory, Richland, Washington. 


\section{Appendix A}

Sampling and Analysis Plan for Hanford Site Low-Level Waste Management Areas 1 to 4 RCRA Interim Status Groundwater Detection Monitoring 


\section{Appendix A}

\section{Sampling and Analysis Plan for Hanford Site Low-Level Waste Management Areas 1 to 4 RCRA Interim Status Groundwater Detection Monitoring}

This Sampling and Analysis Plan (SAP) implements the Resource Conservation and Recovery Act (RCRA) interim status detection monitoring for the Low-Level Waste Management Areas (LLWMAs) 1, 2, 3, and 4. The plan specifies wells (Tables A.1 through A.4), constituents (Tables A.5 and A.6), and frequency of sampling to be scheduled (Tables A.7 through A.10).

Specific constituents required for monitoring at the LLWMAs are set out in Section 3 of the monitoring plan. Table A.5 groups these constituents (where appropriate) by analytical method and defines required practical quantitation limits (PQLs). Laboratory PQLs for the methods used must be equal to or lower than the required PQL. For multi-constituent methods, this table specifies the minimum constituent list required - supplemental constituents may be reported as provided by the laboratory contract. The required PQL is for undiluted samples of normal aliquot size. In some cases, it may be necessary for the laboratory to dilute samples or use a smaller aliquot that will affect the sample-specific detection limit. Table A.5 also describes commonly used analytical methods for the convenience of the reader. However, other methods that meet the requirements are allowed. More information on methods typically used by the project is given in Hartman (2000).

Sample size, bottle type, and preservatives required for the sampling are defined to meet laboratory method and quality assurance (QA) requirements by the Groundwater Performance Assessment Project's Sampling and Analysis Task. Samples for metals analysis are to be filtered through $0.45 \mu \mathrm{m}$ filters (in the field where practicable) as specified in Table A.5.

LLWMA-2 upgradient well 299-W34-7 has shown unusual groundwater composition in recent years. This includes elevated levels of chloride, nitrate, sulfate, calcium, total organic carbon, and total organic halides (see Section 2.3.2.2). Well 299-W34-7 will be monitored for an expanded list of constituents listed in Table A.6.

Monitoring well locations for currently active and dry wells at and surrounding the LLWMAs are shown in Figures A.1 through A.4. These figures include some wells that are not part of the RCRA monitoring network. 
Table A.1. Well Information for Low-Level Waste Management Area 1

\begin{tabular}{||l|c|c|c|c|c|c||}
\hline Well Name & $\begin{array}{c}\text { Well } \\
\text { ID }\end{array}$ & $\begin{array}{c}\text { Elev Top } \\
\text { Screen } \\
(\mathrm{m} \mathrm{msl})\end{array}$ & $\begin{array}{c}\text { Elev Bottom } \\
\text { Screen } \\
(\mathrm{m} \mathrm{msl})\end{array}$ & $\begin{array}{c}\text { Water-Level } \\
\text { Elevation } \\
(\mathrm{m} \mathrm{msl})\end{array}$ & $\begin{array}{c}\text { Water-Level } \\
\text { Date }\end{array}$ & $\begin{array}{c}\text { Thickness Water } \\
\text { Column }(\mathrm{m})\end{array}$ \\
\hline \hline 299-E28-26 & A4822 & 124.79 & 118.70 & 122.23 & $07 / 27 / 2004$ & 3.53 \\
\hline 299-E28-27 & A4823 & 125.53 & 116.08 & 122.20 & $07 / 27 / 2004$ & 6.12 \\
\hline 299-E28-28 & A4824 & 125.65 & 119.56 & 122.19 & $07 / 27 / 2004$ & 2.63 \\
\hline 299-E32-2 & A4830 & 126.03 & 116.59 & 122.18 & $07 / 27 / 2004$ & 5.59 \\
\hline 299-E32-3 & A4831 & 125.85 & 119.76 & 122.20 & $07 / 27 / 2004$ & 2.44 \\
\hline 299-E32-4 & A4832 & 125.05 & 115.90 & 122.18 & $07 / 27 / 2004$ & 6.28 \\
\hline 299-E32-5 & A4833 & 125.49 & 119.09 & 122.20 & $07 / 27 / 2004$ & 3.11 \\
\hline 299-E32-6 & A4834 & 125.65 & 119.25 & 122.19 & $07 / 27 / 2004$ & 2.94 \\
\hline 299-E32-7 & A4835 & 125.65 & 119.25 & 122.20 & $07 / 27 / 2004$ & 2.95 \\
\hline 299-E32-8 & A4836 & 125.11 & 119.01 & 122.17 & $07 / 27 / 2004$ & 3.16 \\
\hline 299-E32-9 & A4837 & 125.62 & 119.52 & 122.19 & $07 / 27 / 2004$ & 2.67 \\
\hline 299-E32-10 & A5432 & 125.95 & 119.85 & 122.19 & $07 / 27 / 2004$ & 2.34 \\
\hline 299-E33-28 & A4852 & 125.03 & 118.32 & 122.21 & $07 / 27 / 2004$ & 3.89 \\
\hline 299-E33-29 & A4853 & 125.59 & 117.36 & 122.19 & $07 / 27 / 2004$ & 4.83 \\
\hline 299-E33-30 & A4855 & 125.13 & 118.42 & 122.23 & $07 / 27 / 2004$ & 3.81 \\
\hline 299-E33-34 & A4859 & 126.49 & 120.39 & 122.20 & $07 / 27 / 2004$ & 1.81 \\
\hline 299-E33-35 & A4860 & 126.68 & 120.28 & 122.17 & $07 / 27 / 2004$ & 1.89 \\
\hline \hline
\end{tabular}

Table A.2. Well Information for Low-Level Waste Management Area 2

\begin{tabular}{||l|c|c|c|c|c|c||}
\hline \hline Well Name & Well ID & $\begin{array}{c}\text { Elev Top } \\
\text { Screen } \\
(\mathrm{m} \mathrm{msl})\end{array}$ & $\begin{array}{c}\text { Elev Bottom } \\
\text { Screen } \\
(\mathrm{m} \mathrm{msl})\end{array}$ & $\begin{array}{c}\text { Water-Level } \\
\text { Elevation } \\
(\mathrm{m} \mathrm{msl})\end{array}$ & $\begin{array}{c}\text { Water-Level } \\
\text { Date } \\
(\mathrm{m})\end{array}$ & $\begin{array}{c}\text { Thickness Water } \\
\text { Column (m) }\end{array}$ \\
\hline \hline 299-E27-8 & A4817 & 125.62 & 116.17 & 122.23 & $07 / 27 / 2004$ & 6.06 \\
\hline 299-E27-9 & A4818 & 125.24 & 117.93 & 122.24 & $07 / 27 / 2004$ & 4.31 \\
\hline 299-E27-10 & A4808 & 126.19 & 117.66 & 122.24 & $07 / 28 / 2004$ & 4.58 \\
\hline 299-E27-11 & A4809 & 126.16 & 119.76 & 122.19 & $07 / 27 / 2004$ & 2.43 \\
\hline 299-E27-17 & A4815 & 125.60 & 119.20 & 122.22 & $07 / 27 / 2004$ & 3.02 \\
\hline 299-E34-2 & A4877 & 125.75 & 119.66 & 122.21 & $07 / 27 / 2004$ & 2.55 \\
\hline 299-E34-5 & A4880 & 128.50 & 122.40 & 122.76 & $07 / 27 / 2004$ & 0.36 \\
\hline 299-E34-7 & A4882 & 125.18 & 121.83 & 122.15 & $07 / 27 / 2004$ & 0.32 \\
\hline 299-E34-9 & A4884 & 126.89 & 120.49 & 122.19 & $07 / 27 / 2004$ & 1.70 \\
\hline 299-E34-10 & A4875 & 126.59 & 120.19 & 122.21 & $07 / 27 / 2004$ & 2.02 \\
\hline 299-E34-12 & A5433 & 126.55 & 120.15 & 122.13 & $07 / 27 / 2004$ & 1.98 \\
\hline
\end{tabular}


Table A.3. Well Information for Low-Level Waste Management Area 3

\begin{tabular}{||l|c|c|c|c|c|c||}
\hline Well Name & Well ID & $\begin{array}{c}\text { Elev Top } \\
\text { Screen } \\
(\mathrm{m} \mathrm{msl})\end{array}$ & $\begin{array}{c}\text { Elev Bottom } \\
\text { Screen } \\
(\mathrm{m} \mathrm{msl})\end{array}$ & $\begin{array}{c}\text { Water-Level } \\
\text { Elevation } \\
(\mathrm{m} \mathrm{msl})\end{array}$ & $\begin{array}{c}\text { Water-Level } \\
\text { Date }\end{array}$ & $\begin{array}{c}\text { Thickness Water } \\
\text { Column }(\mathrm{m})\end{array}$ \\
\hline \hline $299-W 7-3$ & A5009 & 69.60 & 61.06 & 136.33 & $03 / 22 / 2004$ & 75.27 \\
\hline $299-W 7-4$ & A5010 & 143.14 & 134.00 & 136.81 & $03 / 17 / 2004$ & 2.81 \\
\hline $299-W 7-5$ & A5011 & 142.04 & 135.94 & 136.61 & $03 / 29 / 2004$ & 0.67 \\
\hline 299-W7-12 & A5007 & 142.99 & 136.59 & 137.08 & $06 / 8 / 2004$ & 0.49 \\
\hline 299-W8-1 & A5016 & 142.36 & 132.60 & 137.29 & $04 / 27 / 2004$ & 4.69 \\
\hline $299-W 10-14$ & A4891 & 83.42 & 77.33 & 137.48 & $03 / 22 / 2004$ & 60.15 \\
\hline $299-W 10-20$ & A5439 & 142.33 & 136.26 & 137.35 & $04 / 27 / 2004$ & 1.09 \\
\hline $299-W 10-21$ & A5440 & 142.01 & 135.91 & 136.63 & $03 / 22 / 2004$ & 0.72 \\
\hline
\end{tabular}

Table A.4. Well Information for Low-Level Waste Management Area 4

\begin{tabular}{|c|c|c|c|c|c|c||}
\hline Well Name & $\begin{array}{c}\text { Well } \\
\text { ID }\end{array}$ & $\begin{array}{c}\text { Elev Top } \\
\text { Screen } \\
(\mathrm{m} \mathrm{msl})\end{array}$ & $\begin{array}{c}\text { Elev Bottom } \\
\text { Screen } \\
(\mathrm{m} \mathrm{msl})\end{array}$ & $\begin{array}{c}\text { Water-Level } \\
\text { Elevation } \\
(\mathrm{m} \mathrm{msl})\end{array}$ & $\begin{array}{c}\text { Water-Level } \\
\text { Date }\end{array}$ & $\begin{array}{c}\text { Thickness Water } \\
\text { Column }(\mathrm{m})\end{array}$ \\
\hline \hline $299-W 15-15$ & A4919 & 145.19 & 135.44 & 137.80 & $3 / 23 / 2004$ & 2.36 \\
\hline $299-W 15-17$ & A4921 & 80.31 & 77.26 & 137.31 & $3 / 23 / 2004$ & 60.05 \\
\hline $299-W 15-30$ & B2410 & 142.83 & 130.64 & 137.292 & $3 / 23 / 2004$ & 6.65 \\
\hline $299-W 18-21$ & A4933 & 144.51 & 135.37 & 137.91 & $3 / 23 / 2004$ & 2.54 \\
\hline $299-W 18-22$ & A4934 & 77.15 & 67.70 & 137.80 & $3 / 23 / 2004$ & 70.10 \\
\hline $299-W 18-23$ & A4935 & 145.80 & 136.35 & 137.89 & $3 / 23 / 2004$ & 1.54 \\
\hline
\end{tabular}


Table A.5. Analytes, Required Detection Limits, and Filtration Requirements for Constituents at the Low-Level Waste Management Areas

\begin{tabular}{|c|c|c|c|c|}
\hline Analytical Group & Required Constituents & $\begin{array}{c}\text { Required } \\
\mathrm{PQL}^{(\mathrm{a})}\end{array}$ & Filtration & Suggested Method \\
\hline$\overline{\mathrm{pH}}$ & $\overline{\mathrm{pH}}$ & $\overline{\mathrm{NA}}$ & " Unfiltered & "Field ${ }^{(b)}$ \\
\hline Specific Conductance & Specific Conductance & NA & Unfiltered & Field $^{(b)}$ \\
\hline Turbidity & Turbidity & $5 \mathrm{NTU}$ & Unfiltered & Field $^{(b)}$ \\
\hline Temperature & Temperature & $\mathrm{NA}$ & Unfiltered & Field $^{(b)}$ \\
\hline Dissolved oxygen & Dissolved oxygen & $\mathrm{NA}$ & Unfiltered & Field $^{(\mathrm{b})}$ \\
\hline Total Organic Carbon & Total Organic Carbon & $1000 \mu \mathrm{g} / \mathrm{L}$ & Unfiltered & $9060^{(\mathrm{c})}$ \\
\hline Total Organic Halides & Total Organic Halides & $5 \mu \mathrm{g} / \mathrm{L}$ & Unfiltered & $9020^{(\mathrm{c})}$ \\
\hline Alkalinity & Alkalinity & $5000 \mu \mathrm{g} / \mathrm{L}$ & Unfiltered & $310.1^{(d)}$ \\
\hline Anions & \begin{tabular}{|l} 
Chloride \\
Nitrate \\
Nitrite \\
Sulfate
\end{tabular} & $\begin{array}{l}200 \mu \mathrm{g} / \mathrm{L} \\
100 \mu \mathrm{g} / \mathrm{L} \\
100 \mu \mathrm{g} / \mathrm{L} \\
500 \mu \mathrm{g} / \mathrm{L}\end{array}$ & Unfiltered & $300.0^{(\mathrm{d})}$ \\
\hline Metals & \begin{tabular}{|l|} 
Calcium \\
Iron \\
Magnesium \\
Manganese \\
Nickel \\
Sodium \\
Potassium \\
\end{tabular} & $\begin{array}{l}5000 \mu \mathrm{g} / \mathrm{L} \\
100 \mu \mathrm{g} / \mathrm{L} \\
5000 \mu \mathrm{g} / \mathrm{L} \\
15 \mu \mathrm{g} / \mathrm{L} \\
40 \mu \mathrm{g} / \mathrm{L} \\
5000 \mu \mathrm{g} / \mathrm{L} \\
5000 \mu \mathrm{g} / \mathrm{L}\end{array}$ & Filtered & $6010^{(\mathrm{c})}$ \\
\hline Lead & Lead & $3 \mu \mathrm{g} / \mathrm{L}$ & Filtered & $7421^{(\mathrm{c})}$ \\
\hline Mercury & Mercury & $0.2 \mu \mathrm{g} / \mathrm{L}$ & Filtered & $7470^{(\mathrm{c})}$ \\
\hline $\begin{array}{l}\text { Volatile Organic } \\
\text { Compounds }\end{array}$ & $\begin{array}{l}\text { Carbon tetrachloride } \\
\text { Chloroform } \\
\text { Trichloroethene } \\
\text { Tetrachloroethene } \\
\text { Benzene } \\
\text { Toluene } \\
\text { Ethylbenzene } \\
\text { Xylene (total) }\end{array}$ & $\begin{array}{l}5 \mu \mathrm{g} / \mathrm{L} \\
5 \mu \mathrm{g} / \mathrm{L} \\
5 \mu \mathrm{g} / \mathrm{L} \\
5 \mu \mathrm{g} / \mathrm{L} \\
5 \mu \mathrm{g} / \mathrm{L} \\
5 \mu \mathrm{g} / \mathrm{L} \\
5 \mu \mathrm{g} / \mathrm{L} \\
10 \mu \mathrm{g} / \mathrm{L}\end{array}$ & Unfiltered & $8260^{\text {(c) }}$ \\
\hline
\end{tabular}


Table A.5. (contd)

\begin{tabular}{|c|c|c|c|c|}
\hline Analytical Group & Required Constituents & $\begin{array}{c}\text { Required } \\
\text { PQL }^{\text {(a) }}\end{array}$ & Filtration & Suggested Method \\
\hline Phenols & $\begin{array}{l}\text { 2,3,4,6-Tetrachlorophenol } \\
\text { 2,4,5-Trichlorophenol } \\
\text { 2,4,6-Trichlorophenol } \\
\text { 2,4-Dichlorophenol } \\
\text { 2,4-Dimethylphenol } \\
\text { 2,4-Dinitrophenol } \\
\text { 2,6-Dichlorophenol } \\
\text { 2-Chlorophenol } \\
\text { 2-Methylphenol (cresol, o-) } \\
\text { 2-Nitrophenol } \\
\text { 2-secButly-4,6- } \\
\text { dinitrophenol (DNBP) } \\
\text { 4,6-Dintro-2-methylphenol } \\
\text { 4-Chloro-3-methylphenol } \\
\text { 4-Nitrophenol } \\
\text { Pentachlorophenol } \\
\text { Phenol }\end{array}$ & $\begin{array}{l}20 \mu \mathrm{g} / \mathrm{L} \\
60 \mu \mathrm{g} / \mathrm{L} \\
10 \mu \mathrm{g} / \mathrm{L} \\
10 \mu \mathrm{g} / \mathrm{L} \\
10 \mu \mathrm{g} / \mathrm{L} \\
25 \mu \mathrm{g} / \mathrm{L} \\
25 \mu \mathrm{g} / \mathrm{L} \\
10 \mu \mathrm{g} / \mathrm{L} \\
10 \mu \mathrm{g} / \mathrm{L} \\
20 \mu \mathrm{g} / \mathrm{L} \\
10 \mu \mathrm{g} / \mathrm{L} \\
10 \mu \mathrm{g} / \mathrm{L} \\
10 \mu \mathrm{g} / \mathrm{L} \\
20 \mu \mathrm{g} / \mathrm{L} \\
10 \mu \mathrm{g} / \mathrm{L} \\
10 \mu \mathrm{g} / \mathrm{L}\end{array}$ & " Unfiltered & $8040^{(\mathrm{c})}$ or $8270^{(\mathrm{c})}$ \\
\hline $\begin{array}{l}\text { Polychlorinated } \\
\text { biphenyls }\end{array}$ & $\begin{array}{l}\text { Arochlor-1016 } \\
\text { Arochlor-1221 } \\
\text { Arochlor-1232 } \\
\text { Arochlor-1242 } \\
\text { Arochlor-1248 } \\
\text { Arochlor-1254 } \\
\text { Arochlor-1260 }\end{array}$ & $\begin{array}{l}0.5 \mu \mathrm{g} / \mathrm{L} \\
0.5 \mu \mathrm{g} / \mathrm{L} \\
0.5 \mu \mathrm{g} / \mathrm{L} \\
0.5 \mu \mathrm{g} / \mathrm{L} \\
0.5 \mu \mathrm{g} / \mathrm{L} \\
0.5 \mu \mathrm{g} / \mathrm{L} \\
0.5 \mu \mathrm{g} / \mathrm{L}\end{array}$ & Unfiltered & $8082^{(\mathrm{c})}$ \\
\hline \multicolumn{5}{|c|}{$\begin{array}{l}\text { (a) Required maximum Practical Quantitation Limit as defined in laboratory contract. } \\
\text { (b) Field methods are project specific implementations; see Hartman (2000). } \\
\text { (c) EPA } 1986 . \\
\text { (d) EPA } 1979 .\end{array}$} \\
\hline
\end{tabular}


Table A.6. Supplemental Constituents for Low-Level Waste Management Area 2 Well 299-E34-7

\begin{tabular}{|c|c|c|c|c|}
\hline Analytical Group & Required Constituents & $\begin{array}{c}\text { Required } \\
\mathrm{PQL}^{(\mathrm{a})}(\mu \mathrm{g} / \mathrm{L})\end{array}$ & Filtration & Suggested Method \\
\hline $\begin{array}{l}\text { Total Petroleum } \\
\text { Hydrocarbons }\end{array}$ & $\begin{array}{l}\text { diesel range } \\
\text { gasoline range }\end{array}$ & $\overline{2500}$ & Unfiltered & $8015-\mathrm{M}^{(\mathrm{b})}$ \\
\hline Oil and Grease & & 2000 & Unfiltered & \\
\hline Coliform bacteria & & NA & Unfiltered & \\
\hline $\begin{array}{l}\text { Volatile Organic } \\
\text { Compounds - } \\
\text { Appendix IX }\end{array}$ & $\begin{array}{l}\text { 1,1,1,2-Tetrachloroethane } \\
\text { 1,1,1-Trichloroethane } \\
\text { 1,1,2,2-Tetrachloroethane } \\
\text { 1,1,2,2-Tetrachloroethane } \\
\text { 1,1,2-Trichloroethane } \\
\text { 1,1-Dichloroethane } \\
\text { 1,1-Dichloroethene } \\
\text { 1,2,3-Trichloropropane } \\
\text { 1,2-Dibromo-3- } \\
\text { chloropropane } \\
\text { 1,2-Dibromoethane } \\
\text { 1,2-Dichloroethane } \\
\text { 1,2-Dichloroethene(Total or } \\
\text { cis- \& trans-) } \\
\text { 1,2-Dichloropropane } \\
\text { 1,4-Dioxane } \\
\text { 2-Butanone } \\
\text { 4-Methyl-2-Pentanone } \\
\text { Acetone } \\
\text { Acetonitrile } \\
\text { Acrolein } \\
\text { Allyl chloride } \\
\text { Acrylonitrile } \\
\text { Benzene } \\
\text { Bromodichloromethane } \\
\text { Bromoform } \\
\text { Bromomethane } \\
\text { Carbon disulfide } \\
\text { Carbon tetrachloride } \\
\text { Chlorobenzene } \\
\text { Chloroethane } \\
\text { Chloroform } \\
\text { Chloromethane } \\
\text { cis-1,3-Dichloropropene } \\
\text { Dibromochloromethane } \\
\text { Dibromomethane } \\
\text { Ethyl methacrylate } \\
\text { Ethylbenzene } \\
\text { Iodomethane } \\
\end{array}$ & $\begin{array}{l}5 \\
5 \\
5 \\
10 \\
5 \\
5 \\
5 \\
5 \\
5 \\
\\
5 \\
5 \\
20 \\
\\
5 \\
20 \\
10 \\
10 \\
20 \\
100 \\
100 \\
10 \\
100 \\
5 \\
5 \\
5 \\
10 \\
5 \\
5 \\
5 \\
10 \\
5 \\
10 \\
5 \\
5 \\
10 \\
10 \\
5 \\
10 \\
\end{array}$ & Unfiltered & $8260^{(\mathrm{c})}$ \\
\hline
\end{tabular}


Table A.6. (contd)

\begin{tabular}{|c|c|c|c|c|}
\hline Analytical Group & Required Constituents & $\begin{array}{c}\text { Required } \\
\mathrm{PQL}^{(\mathrm{a})}(\mu \mathrm{g} / \mathrm{L})\end{array}$ & Filtration & Suggested Method \\
\hline & $\begin{array}{l}\text { Methacrylonitrile } \\
\text { Methyl methacrylate } \\
\text { Methylenechloride } \\
\text { Styrene } \\
\text { Tetrachloroethene } \\
\text { Toluene } \\
\text { trans-1,2-Dichloroethylene } \\
\text { trans-1,4-Dichloro-2-butene } \\
\text { Trichloroethene } \\
\text { Trichloromonofluoromethane } \\
\text { Vinyl acetate } \\
\text { Vinyl chloride } \\
\text { Xylenes (total or m- \& o- \& } \\
\text { p-) }\end{array}$ & $\begin{array}{l}10 \\
10 \\
5 \\
5 \\
5 \\
5 \\
5 \\
5 \\
5 \\
10 \\
50 \\
10 \\
10\end{array}$ & & \\
\hline $\begin{array}{l}\text { Semi-Volatile } \\
\text { Organic Compounds - } \\
\text { Appendix IX }\end{array}$ & $\begin{array}{l}\text { 1,2,4,5-Tetrachlorobenzene } \\
\text { 1,2,4-Trichlorobenzene } \\
\text { 1,2-Dichlorobenzene } \\
\text { 1,3-Dichlorobenzene } \\
\text { 1,4-Dichlorobenzene } \\
\text { 1,4-Naphthoquinone } \\
\text { 1-Naphthylamine } \\
\text { 2,4,5-Trichlorophenol } \\
\text { 2,4,6-Trichlorophenol } \\
\text { 2,4-Dichlorophenol } \\
\text { 2,4-Dimethylphenol } \\
\text { 2,4-Dinitrophenol } \\
\text { 2,4-Dinitrotoluene } \\
\text { 2,6-Dichlorophenol } \\
\text { 2,6-Dinitrotoluene } \\
\text { 2-Acetylaminofluorene } \\
\text { 2-Chloronaphthalene } \\
\text { 2-Chlorophenol } \\
\text { 2-Methylnaphthalene } \\
\text { 2-Methylphenol (cresol, o-) } \\
\text { 2-Naphthylamine } \\
\text { 2-Nitroaniline } \\
\text { 2-Nitrophenol } \\
\text { 2-Picoline } \\
\text { 3,3'-Dichlorobenzidine } \\
\text { 3-Methylcholanthrene } \\
\text { 3-Nitroaniline } \\
\text { 4,6-Dinitro-2methyl phenol }\end{array}$ & $\begin{array}{l}20 \\
10 \\
10 \\
10 \\
10 \\
50 \\
25 \\
10 \\
10 \\
10 \\
10 \\
25 \\
10 \\
25 \\
10 \\
25 \\
10 \\
10 \\
10 \\
10 \\
25 \\
10 \\
20 \\
20 \\
10 \\
50 \\
10 \\
10\end{array}$ & & $8270^{(\mathrm{c})}$ \\
\hline
\end{tabular}


Table A.6. (contd)

\begin{tabular}{|c|c|c|c|c|}
\hline Analytical Group & Required Constituents & $\begin{array}{c}\text { Required } \\
\mathrm{PQL}^{(\mathrm{a})}(\mu \mathrm{g} / \mathrm{L})\end{array}$ & Filtration & Suggested Method \\
\hline & $\begin{array}{l}\text { 4-Aminobiphenyl } \\
\text { 4-Chloro-3-methylphenol } \\
\text { 4-Chloroaniline } \\
\text { 4-Chlorophenylphenyl ether } \\
\text { 4-Methylphenol (cresol, p-) } \\
\text { 4-Nitroaniline } \\
\text { 4-Nitrophenol } \\
\text { 4-Nitroquinoline-1-oxide } \\
\text { 5-Nitro-o-toluidine } \\
\text { Acenaphthene } \\
\text { Acenaphthylene } \\
\text { Acetophenone } \\
\text { Aniline } \\
\text { Anthracene } \\
\text { Benzo(a)anthracene } \\
\text { Benzo(a)pyrene } \\
\text { Benzo(b)fluoranthene } \\
\text { Benzo(ghi)perylene } \\
\text { Benzo(k)fluoranthene } \\
\text { Bis(2-Chloroethoxy)methane } \\
\text { Bis(2-chloro-1- } \\
\text { methylethyl)ether } \\
\text { Bis(2-chloroethyl) ether } \\
\text { Bis(2-ethylhexyl) phthalate } \\
\text { Butylbenzylphthalate } \\
\text { Chlorobenzilate } \\
\text { Chrysene } \\
\text { Diallate } \\
\text { Dibenz[a,h]anthracene } \\
\text { Dibenzofuran } \\
\text { Diethylphthalate } \\
\text { Dimethoate } \\
\text { Dimethyl phthalate } \\
\text { Di-n-butylphthalate } \\
\text { Di-n-octylphthalate } \\
\text { Disulfoton } \\
\text { Ethyl methanesulfonate } \\
\text { Famphur } \\
\text { Fluoranthene } \\
\text { Fluorene } \\
\text { Hexachlorobenzene }\end{array}$ & 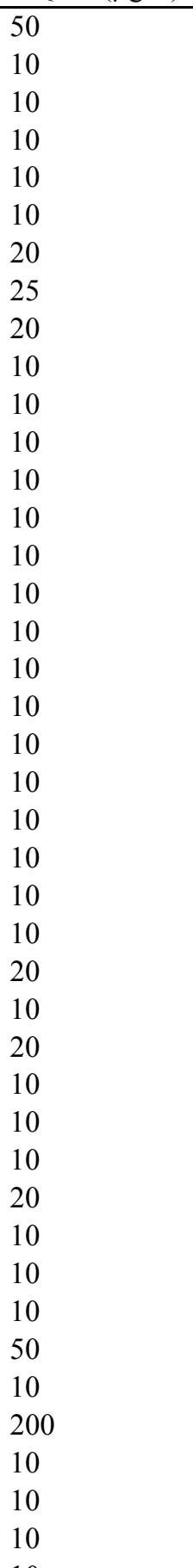 & & \\
\hline
\end{tabular}


Table A.6. (contd)

\begin{tabular}{|c|c|c|c|c|}
\hline Analytical Group & Required Constituents & $\begin{array}{c}\text { Required } \\
\mathrm{PQL}^{(\mathrm{a})}(\mu \mathrm{g} / \mathrm{L})\end{array}$ & Filtration & Suggested Method \\
\hline & $\begin{array}{l}\text { Hexachlorocyclopentadiene } \\
\text { Hexachloroethane } \\
\text { Hexachlorophene } \\
\text { Hexachloropropene } \\
\text { Indeno(1,2,3-cd)pyrene } \\
\text { Isodrin } \\
\text { Isophorone } \\
\text { Isosafrole } \\
\text { Kepone } \\
\text { m-Dinitrobenzene } \\
\text { Methapyrilene } \\
\text { Methyl methanesulfonate } \\
\text { Methyl parathion } \\
\text { Naphthalene } \\
\text { Nitrobenzene } \\
\text { Nitrosopyrrolidine } \\
\text { N-Nitrosodiethylamine } \\
\text { N-Nitrosodimethylamine } \\
\text { N-Nitrosodi-n-butylamine } \\
\text { N-Nitroso-di-n- } \\
\text { dipropylamine } \\
\text { N-Nitrosodiphenylamine } \\
\text { N-Nitrosomethylethylamine } \\
\text { N-Nitrosomorpholine } \\
\text { N-Nitrosopiperidine } \\
\text { O,O,O-Triethyl } \\
\text { phosphorothioate } \\
\text { O,O-Diethyl 0-2-pyrazinyl } \\
\text { phosphorothioa } \\
\text { o-Toluidine } \\
\text { Parathion } \\
\text { Pentachlorobenzene } \\
\text { Pentachloroethane } \\
\text { Pentachloronitrobenzene } \\
\text { (PCNB) } \\
\text { Pentachlorophenol } \\
\text { Phenacetin } \\
\text { Phenanthrene } \\
\text { Phenol } \\
\text { Phorate } \\
\text { p-Phenylenediamine } \\
\text { - }\end{array}$ & 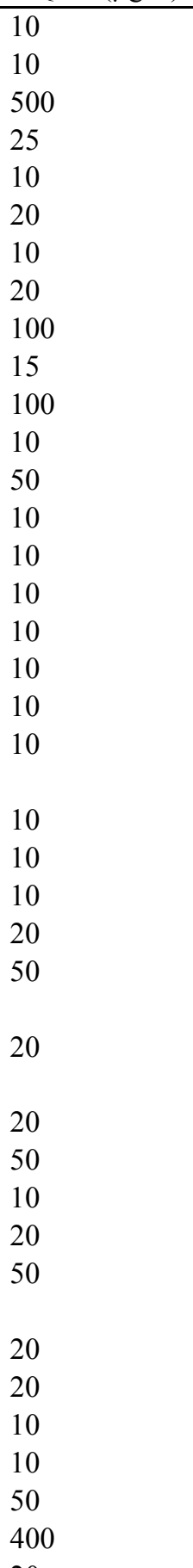 & & \\
\hline
\end{tabular}


Table A.6. (contd)

\begin{tabular}{||l|l|l|l|l||}
\hline & & Required \\
Analytical Group & \multicolumn{1}{|c||}{ Required Constituents } & $\mathrm{PQL}^{(\mathrm{a})}(\mu \mathrm{g} / \mathrm{L})$ & Filtration & Suggested Method \\
\hline & Pyrene & 10 & & \\
& Pyridine & 20 & & \\
& Safrol & 20 & & \\
& sym-Trinitrobenzene & 100 & & \\
& Tetraethyl & 50 & & \\
\hline (a) Required PQL: Required maximum Practical Quantitation Limit as defined in laboratory contract. \\
(b) Modified from EPA-SW-846 method (EPA 1986). \\
(c) EPA 1986. \\
(d) EPA 1979.
\end{tabular}




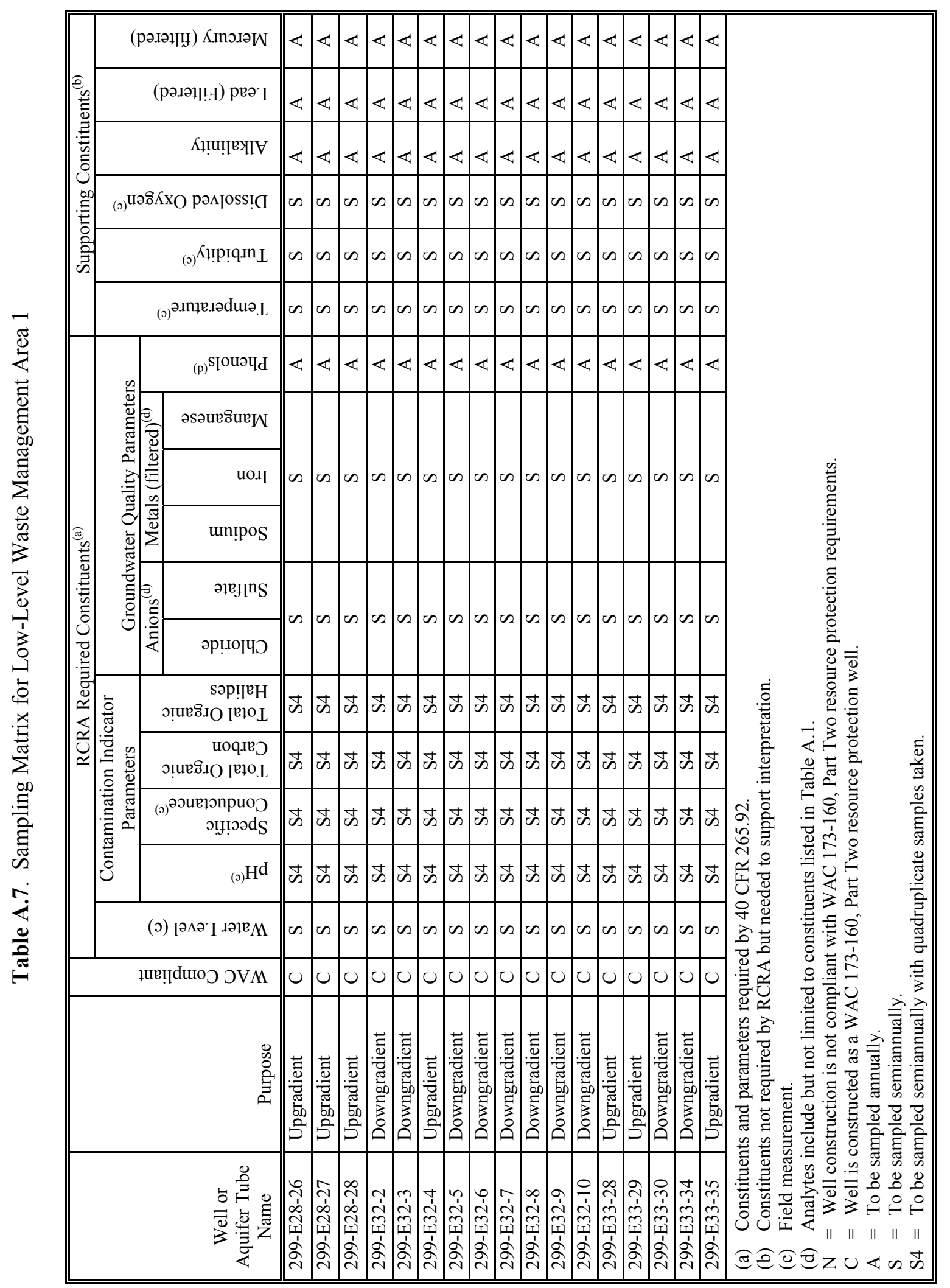




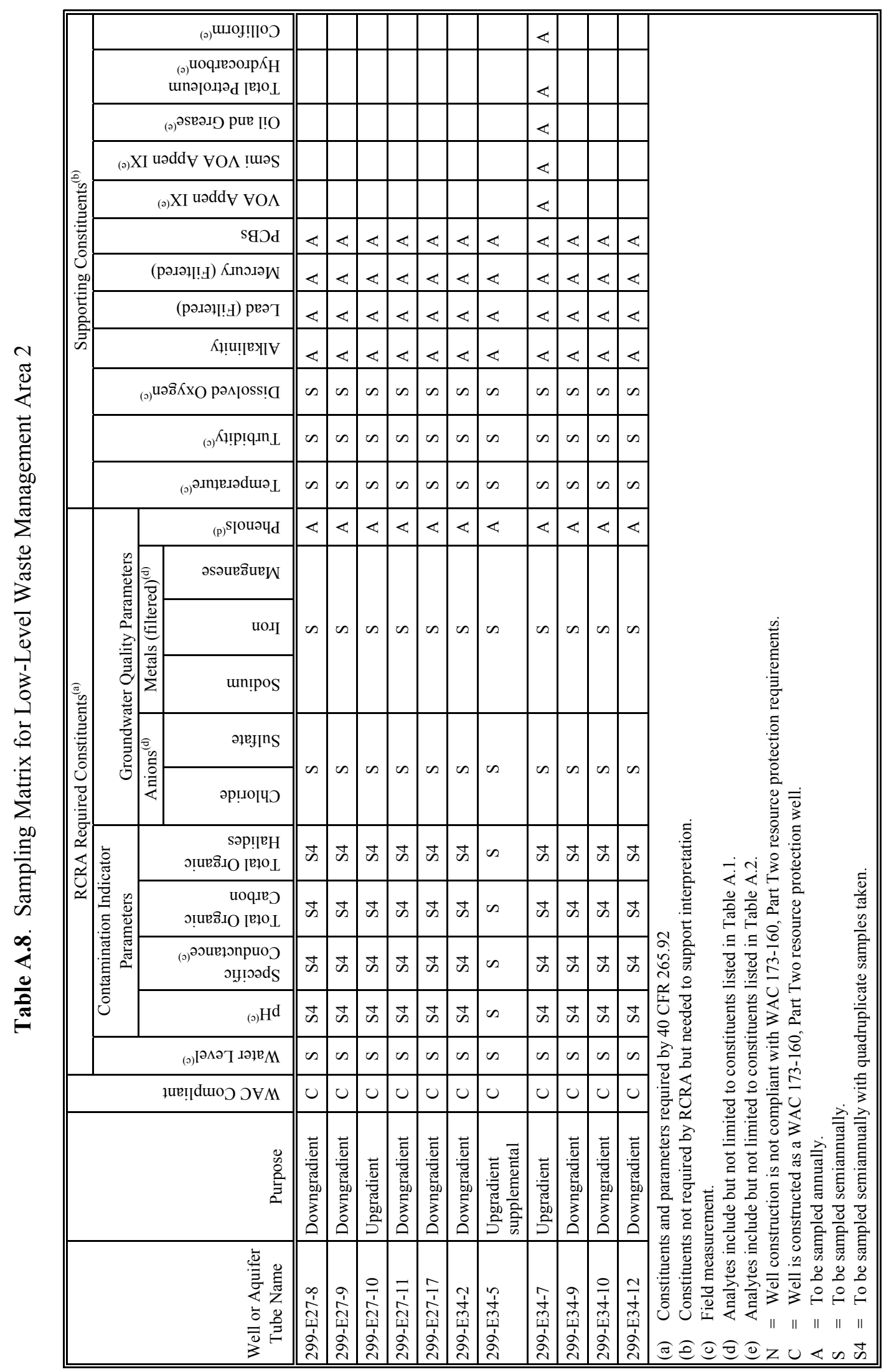

A. 12 


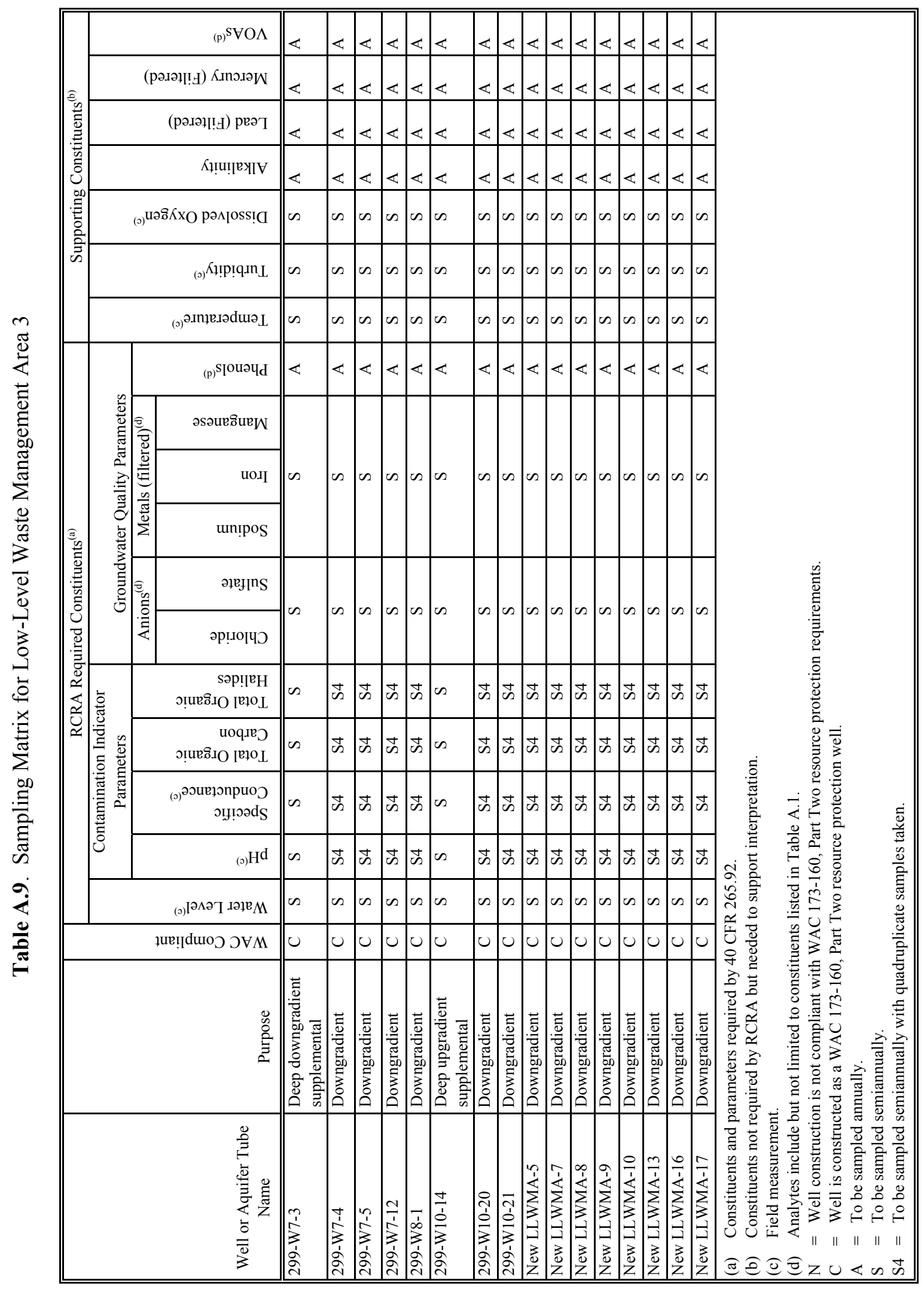

A. 13 


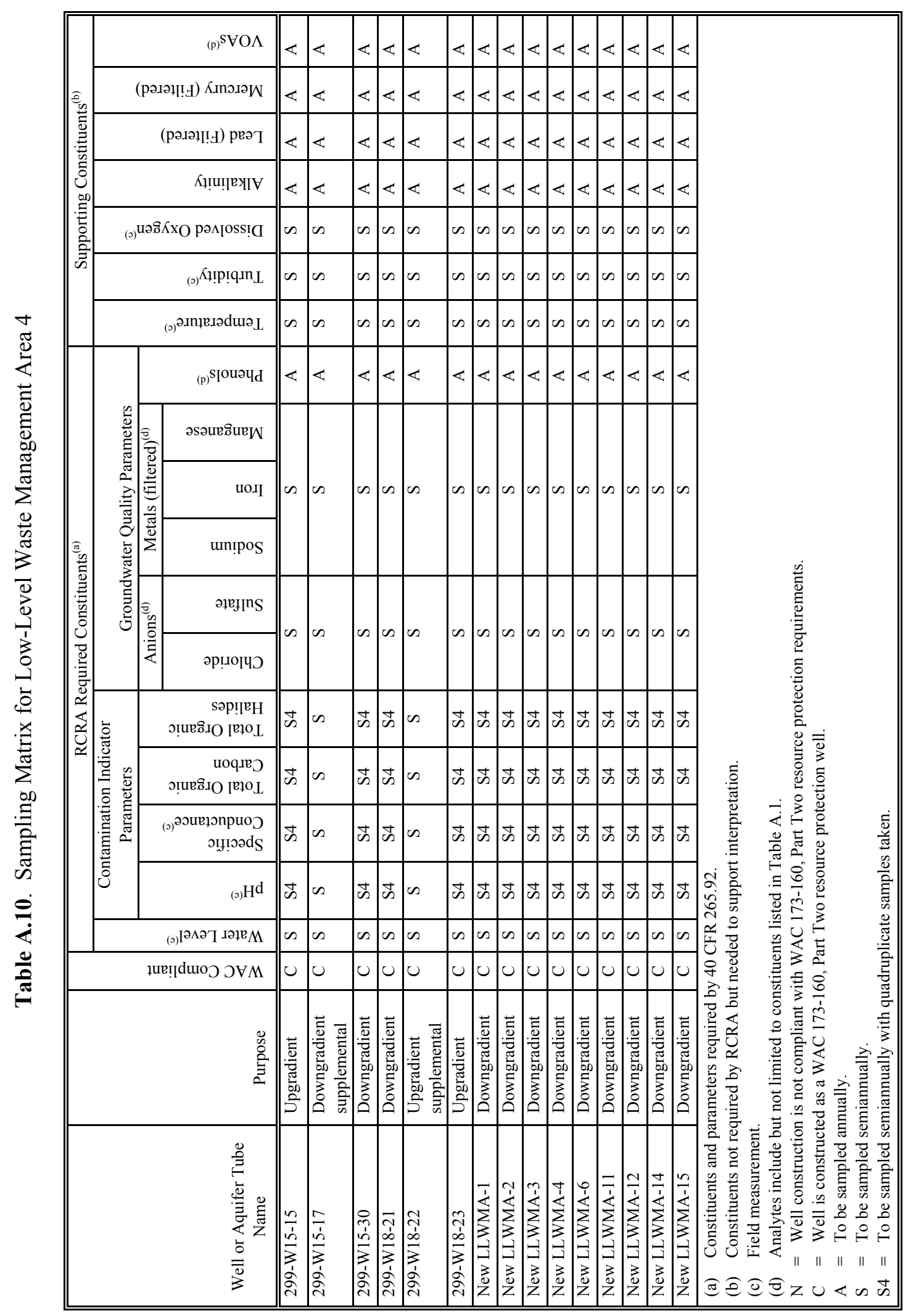

A. 14 


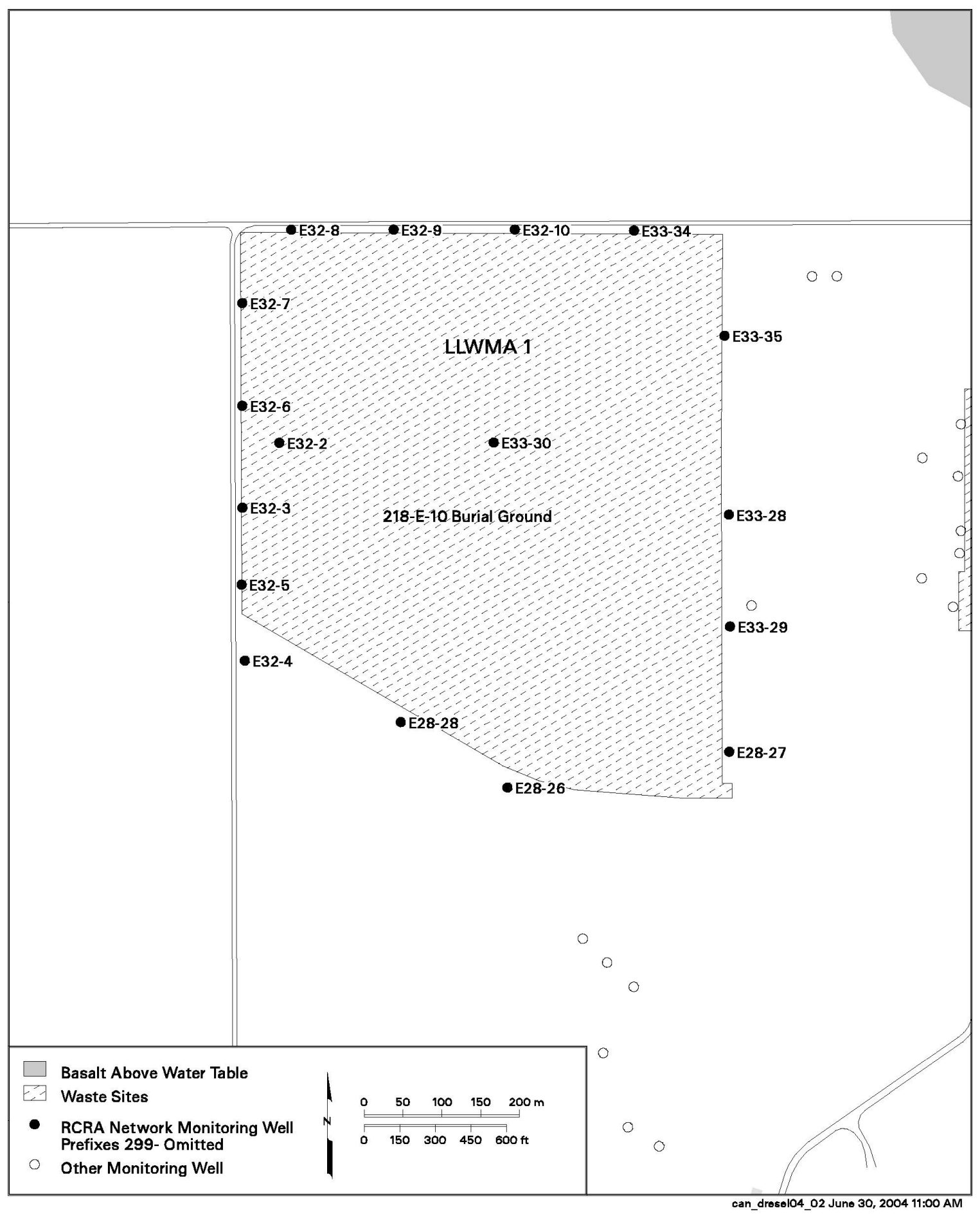

Figure A.1. Well Locations for LLWMA-1 RCRA Monitoring 


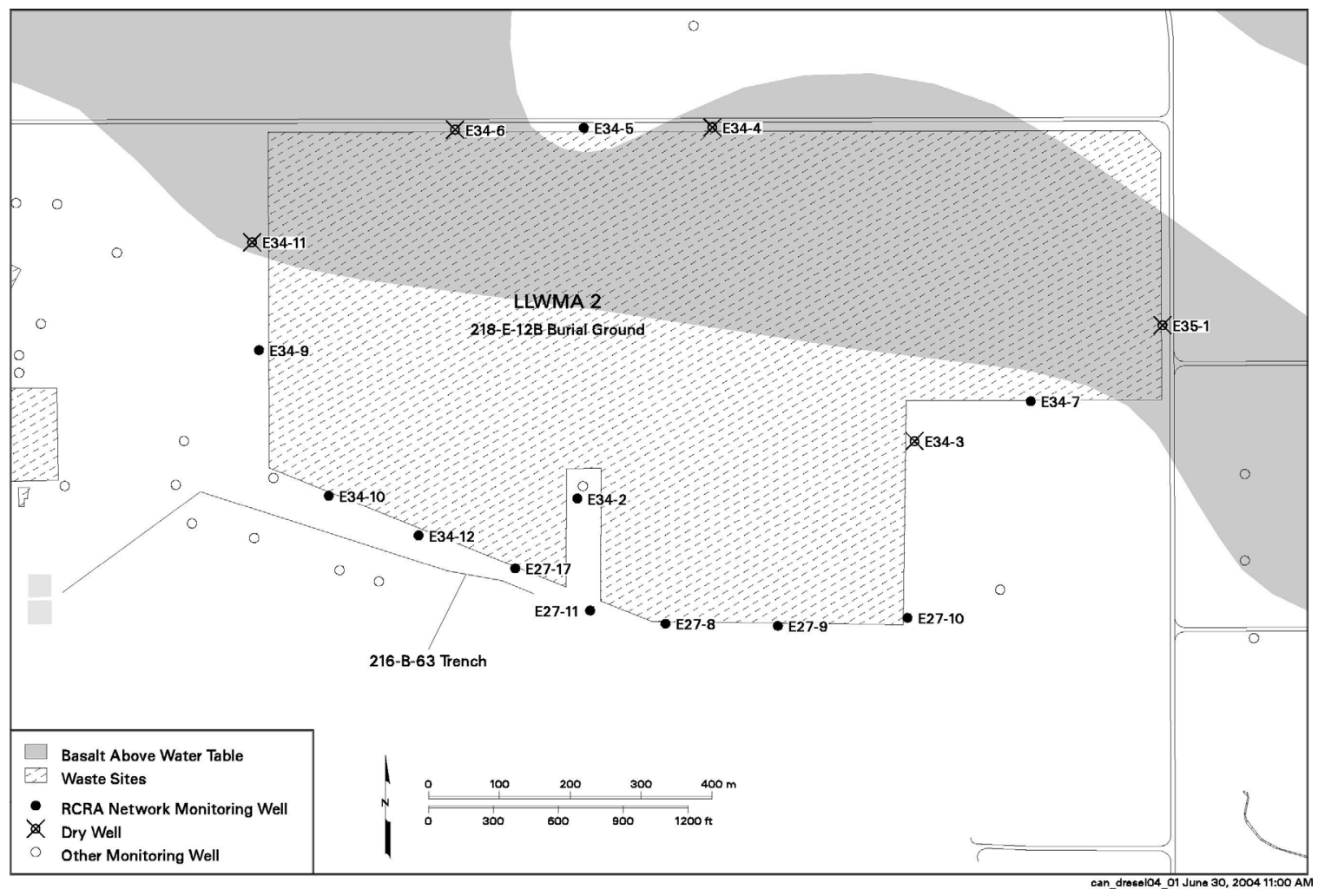

Figure A.2. Well Locations for LLWMA-2 RCRA Monitoring 


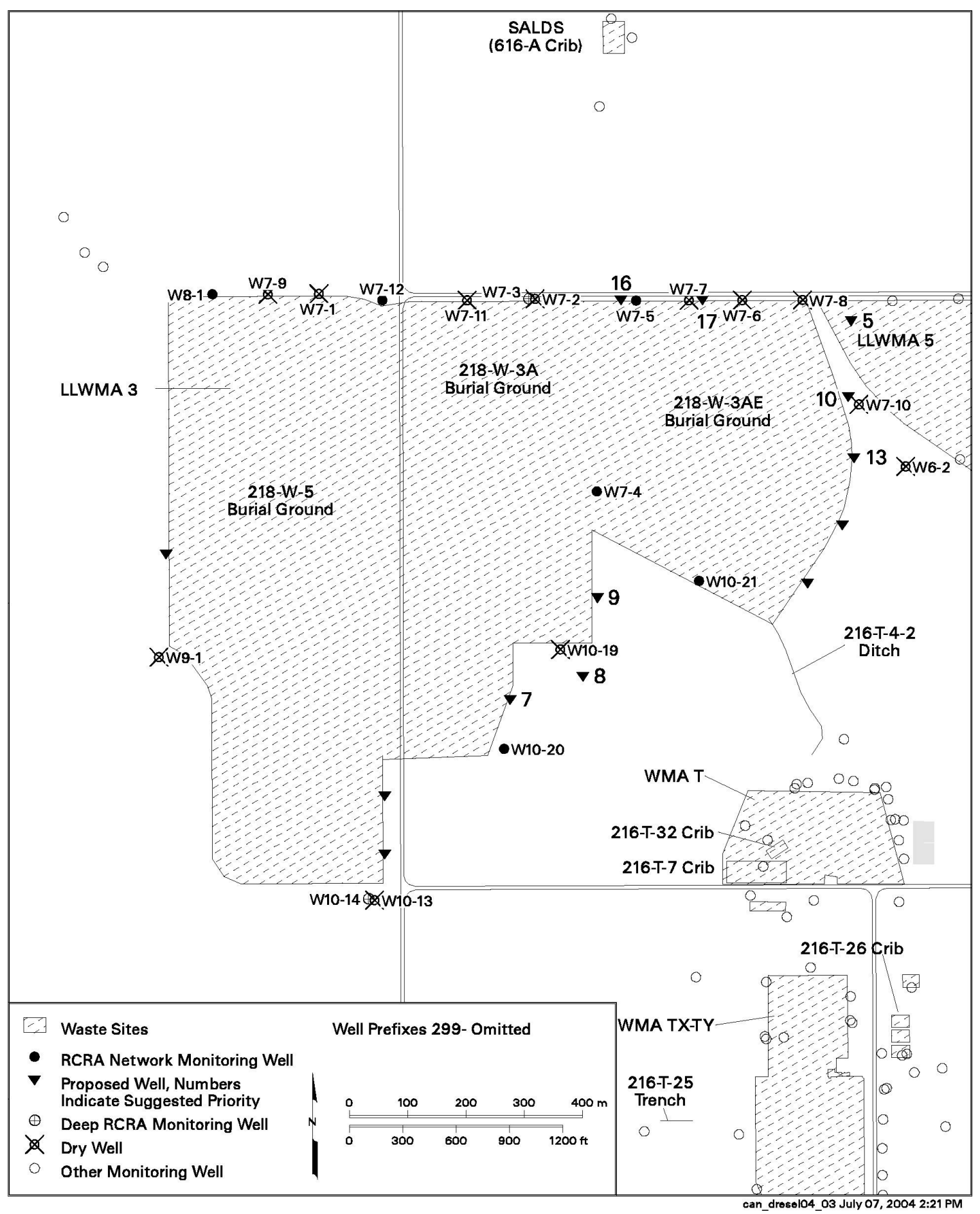

Figure A.3. Well Locations for LLWMA-3 RCRA Monitoring 


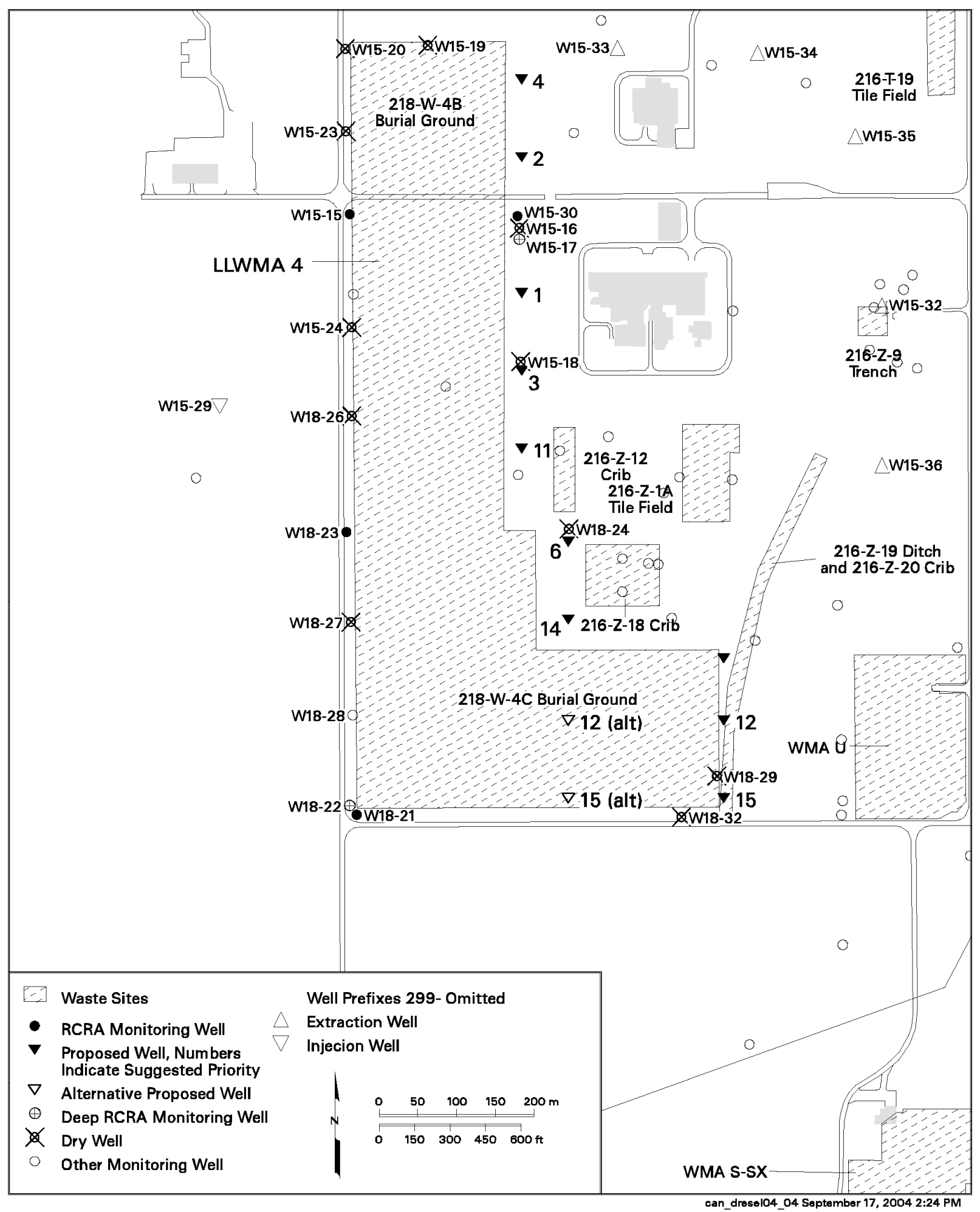

Figure A.4. Well Locations for LLWMA-4 RCRA Monitoring 


\section{References}

40 CFR 265.92. "Sampling and Analysis." Code of Federal Regulations, U.S. Environmental Protection Agency.

EPA. 1979. Methods for Chemical Analysis of Water and Wastes. EPA-600/4-79-020, U.S. Environmental Protection Agency, Washington, D.C.

EPA. 1986. Test Methods for Evaluating Solid Waste: Physical/Chemical Methods, SW-846, Third Edition. Office of Solid Waste and Emergency Response, U.S. Environmental Protection Agency, Washington, D.C. Available online at: http://www.epa.gov/epaoswer/hazwaste/test/sw846.htm

Hartman MJ (ed). 2000. Hanford Site Groundwater Monitoring: Setting, Sources, and Methods. PNNL-13080, Pacific Northwest National Laboratory, Richland, Washington.

Resource Conservation and Recovery Act. 1976. Public Law 94-580, as amended, 90 Stat. 2795, 42 USC 6901 et seq.

WAC 173-160, Part Two. "General Requirements for Resource Protection Well Construction and Geotechnical Soil Borings.” Washington Administrative Code, Olympia, Washington. 


\section{Appendix B}

Groundwater Quality Assessment Program Outline 


\section{Appendix B \\ Groundwater Quality Assessment Program Outline}

This section presents the outline of a groundwater quality assessment program as required by 40 CFR 265 93. The outline describes a more comprehensive groundwater monitoring program capable of determining whether hazardous waste or hazardous waste constituents have entered groundwater, the rate and extent of migration of hazardous waste or hazardous waste constituents in the groundwater, and the concentrations of hazardous waste constituents in the groundwater. The plan must specify the number, location, and depth of wells; sampling and analytical methods for those hazardous wastes or hazardous waste constituents in the facility; evaluation procedures including any use of previously gathered groundwater quality information; and a schedule of implementation.

If analyses of indicator parameters confirm a significant increase (or $\mathrm{pH}$ decrease), a specific groundwater quality assessment plan will be submitted within 15 days. The determination of rate and extent of contaminant migration and concentrations of hazardous waste or hazardous waste constituents in groundwater must be made on a quarterly basis until final closure of the facility or until the facility returns to detection monitoring (if the facility is determined not to have impacted groundwater with hazardous materials).

The outline of the groundwater quality assessment program presented in Table B.1 describes actions that may be taken to meet the objectives of the assessment. The nature of the particular indication of impact from the facility and the site-specific conditions may require alteration to the outlined program. The program may be implemented in a phased approach, so that certain activities are performed, based on the results of prior steps.

\section{Reference}

40 CFR 265.93. "Preparation, Evaluation, and Response.” Code of Federal Regulations, U.S. Environmental Protection Agency. 
Table B.1. Sample Groundwater Quality Assessment Plan Outline

Introduction

Statement of the problem

Regulatory background

Background Information

Facility description

Geology and hydrogeology

Summary of Monitoring Results to Date

Well network

Water level results

Analytical results

Preliminary Interpretation of Previous Monitoring Results

Regional and upgradient contamination

Potential TSD contamination

Assessment Plan

Planned Approach

Expansion of well network

Collection and analysis of geologic/hydrogeologic data

Collection and analysis of groundwater quality data

Quality assurance/quality control

Proposed hydrologic and water quality interpretation methods

Method of determining rate and extent of contaminant movement

Implementation Schedule

Reporting

Sampling and Analysis Plan 


\section{Distribution}

No. of

Copies

ONSITE

4 DOE, Richland Operations Office

M. S. Collins

K. M. Thompson

DOE Administrative Record

DOE Reading Room

6 Fluor Hanford, Inc.

J. V. Borghese

A. Miskho

A. L. Prignano

V. J. Rohay

D. Saueressig

J. A. Winterhalder
No. of

Copies

Washington State Department of Ecology

D. Goswami

H0-57

A6-38

A6-38

H6-08

$\mathrm{H} 2-53$

E6-35

H8-40

$\mathrm{H} 8-40$

K6-81

T4-04

E6-35
13 Pacific Northwest National Laboratory

P. E. Dresel (6)

K6-96

J. S. Fruchter

K6-96

M. J. Hartman

K6-96

S. P. Luttrell

K6-96

D. L. Stewart

K6-96

E. C. Thornton

K6-96

Hanford Technical Library (2)

P8-55

Distr.1 